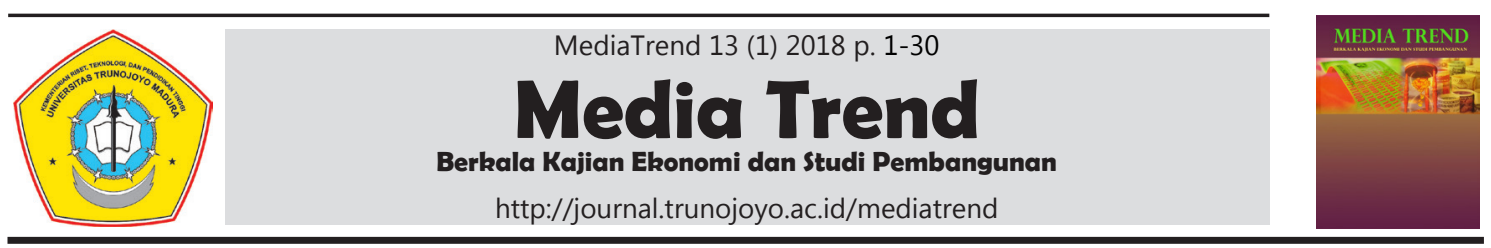

\title{
Aspek Hukum dan Ekonomi Dalam Penetapan Batas Luas Penggunaan La- han Untuk Usaha Perkebunan Sawit Yang Selaras Dengan Asas Efisiensi dan Berkeadilan dalam Mewujudkan Kesejahteraan Masyarakat
}

\author{
Bayu Kharisma $^{1^{*}}$, Rudi Kurniawan ${ }^{2}$ \\ 1,2 Departemen Ilmu Ekonomi, Fakultas Ekonomi dan Bisnis, Universitas Padjadjaran
}

\begin{tabular}{l} 
Informasi Artikel \\
\hline Sejarah artikel: \\
Diterima September 2017 \\
Disetujui Februari 2018 \\
Dipublikasikan Maret \\
2018 \\
\hline Keywords: \\
Plantation Sector, \\
Oil Palm, \\
Efficiency Principle And \\
Fair Principle, \\
Land Tenure Gap, \\
Legislation, \\
System Dynamics
\end{tabular}

System Dynamics

\begin{abstract}
A B S T R ACT
The role of the plantation in the provision of business opportunities is increasingly important as the number of Indonesians continues to increase while the opportunities for work in other sub-sectors are not rapid. By 2015, Indonesia's population will reach 255.5 million people and 20 years later (in 2035) will be 305.7 million people (BPS, 206). To date, almost half of Indonesia's population lives in rural areas, which will rely on plantations as a source of income. The purpose of this study is to see whether or not it is necessary to establish a maximum permit limit on the use of land for oil palm plantations from the economic and legal aspects by considering the efficiency and fairness aspects, since the commodity is a national strategic flagship. The methodology used in this review is built on the System dynamics framework through Causal Loop Diagram (CLD) which shows the relevant relationships and feedback between model parameters based on efficiency and fairness principles. In addition, the analysis of legislation related to the limitation of land area in the oil palm plantation business in Indonesia. Based on the results of the regulatory analysis analysis, it is necessary to stipulate the regulation on limiting the maximum area of land use for oil palm plantation business in 1 (one) company or group of plantation companies for the commodities / plantations of oil palm plantations. In addition, the results based on system dynamics indicate that the determination of the maximum extent of land use in the oil palm plantation business should be done by considering the principle of justice, the principle of efficiency and regulation and policy and prioritizing environmental sustainability. Implementation of fairness principle in the organization of plantation business is more complex than the application of efficiency principle. Fairness is built by social aspects, technical aspects and economic aspects, while the principle of efficiency is more determined by economic aspects.
\end{abstract}

Penulis korespondensi:

E-mail: bayu.kharisma@unpad.ac.id

DOI: http://dx.doi.org/10.21107/mediatrend.v13i1.3143

2460-7649 (c) 2018 MediaTrend. All rights reserved. 


\section{Pendahuluan}

Perkebunan merupakan salah satu sub-sektor yang mempunyai peranan penting dan strategis dalam pembangunan nasional. Data Produk Domestik Bruto (PDB) nasional tahun 2015 menunjukkan bahwa rata-rata kontribusi PDB sub sektor perkebunan terhadap PDB nasional tahun 2015 diperkirakan sebesar 3,90\% berdasarkan harga konstan 2010 (BPS, 2015).

Pentingnya peranan perkebunan selain sebagai penghasil devisa, pemenuhan kebutuhan konsumsi dalam negeri dan bahan baku berbagai industri dalam negeri (termasuk energi terbarukan) juga yang tak kalah pentingnya adalah sebagai penyedia peluang bekerja/berusaha bagi masyarakat Indonesia. Peranan sub sektor perkebunan dalam penyediaan peluang berusaha/bekerja semakin penting, mengingat jumlah penduduk Indonesia terus bertambah sedangkan peluang berusaha/ bekerja yang diciptakan sub sektor lain tidak berlangsung sangat pesat. Menurut data BPS, pada tahun 2015 jumlah penduduk Indonesia sudah mencapai 255,5 juta jiwa dan 20 tahun kemudian (tahun 2035) akan menjadi 305,7 juta jiwa. Sampai dengan saat ini dan 20 tahun ke depan hampir setengah dari penduduk Indonesia masih tinggal di pedesaan yang tentunya akan mengandalkan perkebunan sebagai sumber pendapatannya.

Dalam kegiatan usaha perkebunan, sumber daya lahan merupakan salah satu elemen daya/atau kekuatan produksi (force of production) yang penting karena lahan itulah kegiatan produksi komoditas perkebunan sebagai penghasil "surplus". Terkait dengan keberadaan sumber daya lahan sebagai elemen "kekuatan produksi", maka muncul berbagai pola hubungan antara manusia dan sumber daya lahan serta hubungan sosial atau kelembagaan di antara para pelaku usaha perkebunan atau antara pelaku usaha perkebunan dengan pihak lain agar mereka dapat menguasai dan memanfaatkan sebidang sumber daya lahan yang mereka perlukan.

Pada sub sektor perkebunan, sumber daya lahan yang secara teknis layak untuk mengusahakan tanaman perkebunan tertentu akan diperebutkan di antara para pelaku usaha yang memiliki kemampuan teknis dan finansial berbeda. Statistik Perkebunan Indonesia tahun 2015-2017 (Ditjenbun, 2016) menunjukkan bahwa luas sumber daya lahan yang telah digunakan untuk usaha perkebunan di Indonesia pada tahun 2015 mencapai 23,21 juta hektar, dan $48,52 \%$ dari total areal tersebut $(11,26$ juta hektar) digunakan untuk usaha perkebunan kelapa sawit.

Para pelaku usaha perkebunan di Indonesia terdiri dari: 1) Perusahaan Perkebunan Besar Swasta (PMDN dan PMA); 2) Perusahaan Perkebunan Besar Negara; dan 3) Pekebun. Adanya perbedaan kemampuan teknis dan finansial di antara para pelaku usaha tersebut lebih lanjut akan mempengaruhi tingkat kemampuan mereka dalam menguasai besaran luas lahan yang akan digunakannya dalam melakukan usaha perkebunan. Oleh sebab itu, hadirnya pemerintah melalui kebijakan yang mengatur besaran luas penguasaan sumber daya lahan untuk usaha perkebunan sangat diperlukan, agar usaha tersebut dapat berjalan berdasarkan asas efisiensi dan asas berkeadilan secara bersamaan. Bila tidak demikian, maka akan timbul kesenjangan penguasaan lahan yang akan mendorong semakin tajamnya kesenjangan ekonomi dan sosial sehingga kemudian akan memicu terjadinya konflik sosial vertikal maupun horizontal. Lebih lanjut, bila hal ini terjadi maka keberlanjutan penyelenggaraan usaha perkebunan secara keseluruhan akan terganggu.

Dalam pola hubungan sosial/kelembagaan agraria atau penguasaan lahan, pemerintah dapat melakukan peranan sebagai pengatur hubungan antara manusia dengan tanah, manusia dengan manusia (hubungan sosial/kelembagaan agraria), 
tetapi dapat juga sebagai pihak yang memiliki klaim penguasaan tanah dengan nama "tanah negara". Di Indonesia, penguasaan tanah oleh negara yang juga disebut Hak Menguasai dari Negara (HMN) dilandasi oleh UUD 45 pasal 33 ayat (3) dan kemudian dituangkan dalam UUPA pasal 2 ayat (2). Hak negara tersebut merupakan hak menguasai yang sama dengan hak communes atau hak imperium. Sebenarnya, sebagaimana juga dikemukakan oleh Nasution (2000) hak menguasai dari negara (HMN) mengandung pengertian tentang perlunya peranan aktif dari pemerintah dalam mengatur penguasaan dan penataan penggunaan tanah untuk mencapai tujuan nasional.

Struktur penguasaan lahan pada usaha perkebunan, berbeda antar komoditas perkebunan. Pada usaha kelapa sawit dan teh, penguasaan lahan didominasi oleh perkebunan besar, masing-masing $59,7 \%$ dan $53,4 \%$. Pada usaha kelapa sawit, penguasaan lahan oleh perusahaan swasta jauh lebih dominan dari pada perusahaan negara, yaitu masing-masing $53,1 \%$ dan $6,6 \%$. Sejalan dengan struktur penguasaan lahan tersebut, ketimpangan penguasaan lahan tertinggi terjadi pada usaha kelapa sawit berada pada kategori "ketimpangan cukup tinggi", dimana 40\% pelaku usaha kebun kelapa sawit hanya menguasai $15,7 \%$ total lahan yang digunakan untuk usaha kelapa sawit. Bersamaan dengan itu, luas pemilikan lahan setiap pekebun umumnya masih jauh lebih kecil dari luas lahan ideal yang diperlukan agar pekebun mampu mengelola kebun secara intensif, mampu membiayai peremajaan kebun, dan mensejahterakan keluarganya.

Bila kondisi ketimpangan terus tumbuh bersamaan dengan masih adanya pengangguran dan kemiskinan di wilayahwilayah usaha perkebunan, maka kondisi ini akan mendorong terjadinya konflik sosial. Kondisi ini bila dibiarkan sangat potensial menimbulkan iklim usaha yang tidak kondusif dan kemudian akan mengganggu berlangsungnya usaha perkebunan secara keseluruhan. Sub-sektor perkebunan masih perlu ditingkatkan perannya dalam penyediaan lapangan berusaha/bekerja dan dalam mengatasi kemiskinan" mengingat angkatan kerja di Indonesia terus meningkat sejalan pertumbuhan penduduk $(1,4 \%$ / tahun periode 2000-2014), pengangguran masih terus terjadi karena pertumbuhan angkatan kerja lebih kecil dari pada peluang bekerja/berusaha (tahun 2001 sebanyak 8 juta dan tahun 2013 sebanyak 7,3 juta), dan kemiskinan juga masih terjadi di seluruh provinsi (tahun 2015 sebanyak $11,7 \%$ penduduk Indonesia masih miskin). Penduduk miskin tersebut terjadi baik pada kelompok penduduk yang tidak bekerja sebesar $26 \%$ ataupun yang bekerja di sektor pertanian sebesar $36 \%$ (termasuk yang bekerja di sub sektor perkebunan) maupun yang bekerja di sektor non pertanian sebesar 38\%.

Berkaitan dengan masih tingginya permasalahan ketimpangan penguasaan lahan pada usaha kelapa sawit maka tujuan dalam kajian ini adalah menganalisa perlu atau tidaknya dilakukannya penetapan batas luas maksimum penggunaan lahan untuk usaha perkebunan kelapa sawit dengan memperhatikan aspek ekonomi dan hukum yang berlandaskan aspek efisiensi dan berkeadilan, mengingat komoditas tersebut merupakan unggulan strategis nasional. Meskipun dalam pasal 14 ayat 1 UU No 39 tahun 2014 tentang Perkebunan yang diamanatkan adalah penetapan batasan "luas maksimum" dan "luas minimum" penggunaan lahan untuk Usaha Perkebunan, tetapi tinjauan ini hanya fokus pada penetapan batasan "luas maksimum". Hal ini sejalan dengan upaya pemerintah untuk mencegah penguasaan lahan yang melampaui batas dan monopoli swasta, sebagaimana tercantum pada pasal 7 dan pasal 12 ayat 3 dalam UU RI Nomor 5 Tahun 1960 tentang Peraturan Dasar Pokok-Pokok Agraria. 
Selain itu, kebijakan yang dilakukan oleh Pemerintah mengacu pada kelestarian lingkungan yang berlandaskan UU. No. 32 Tahun 2009 tentang Perlindungan dan Pengelolaan Lingkungan Hidup.

\section{Metodologi Penelitian}

Kompleksitas yang saling terkait antara aspek sosial, ekonomi, teknis serta regulasi dan kebijakan pada pengusahaan lahan komoditas kelapa sawit maka diperlukan pemahaman yang komprehensif dan holistik agar tidak terjadi kesalahan dalam melakukan analisis untuk pengambilan kesimpulan maupun penentuan keputusan yang dilakukan oleh pemerintah.

Model yang digunakan dalam tinjauan ini dibangun dengan kerangka kerja System dynamics melalui Causal Loop Diagram (CLD) yang menunjukkan hubungan yang relevan dan feedback antara parameter model yang berlandaskan asas efisiensi dan asas berkeadilan dan peraturan perundang-undangan yang terkait dengan pembatasan luas lahan pada usaha perkebunan kelapa sawit di Indonesia.

\section{Metode Dinamika Sistem (System Dy- namic)}

Metodologi dinamika sistem merupakan strategi yang cocok untuk menjawab pertanyaan penelitian "how" dan "why", dimana pertanyaan ini dijawab dengan pendekatan struktural. Pertanyaan dijelaskan dengan menggambarkan hubungan kausalitas dan saling ketergantungan satu faktor dengan faktor lainnya. Struktur pada perancangan model ditentukan oleh konseptualisasi literatur tertulis, tujuan, informasi keputusan (expert meeting) dan tertulis (data sekunder) dengan menggunakan kaidah "feedback-loops". Penggunaan Causal Loop Diagram (CLD) dengan sistem archetype menunjukkan hubungan yang relevan dan feedback loop antar parameter model.

\section{Prosedur Dinamika Sistem}

Metode pemodelan dinamika sistem pada dasarnya bertujuan untuk menemukan dan menunjukan proses umpan balik (feedback). Pembelajaran dari struktur yang dibangun berdasarkan kepada umpan balik dengan mengumpulkan feedback informasi mengenai dunia nyata. Langkah-langkah yang dilakukan dalam pemodelan sistem adalah sebagai berikut (Sterman, 2000): a) Perumusan masalah: identifikasi persoalan, variabel kunci, waktu terjadinya masalah, historis perilaku dari variabel kunci; b) Formulasi hipotesis dinamika: problematisasi secara konseptual, fokus terhadap konsekuensi dari struktur feedback, pemetaan dengan menggunakan diagram hubungan sebab akibat; c) Formulasi model simulasi: kaidah keputusan, perkiraan parameter, pengujian konsistensi; d) Pengujian: membandingkan dengan perilaku historis, pengujian pada kondisi ekstrim, sensitivitas; e) Desain kebijakan dan evaluasi: skenario kebijakan, perancangan kebijakan, analisis sensitivitas, dan interaksi antar kebijakan.

\section{Pendekatan Cara Berpikir Sistem (Sys- tem Thinking)}

System thinking berperan sebagai bahasa dan alat dalam mengkomunikasikan suatu persoalan penentuan batas besaran luas maksimum penggunaan lahan pada usaha perkebunan agar lebih mudah dipahami dan komunikatif. Terdapat beberapa prinsip yang mendasar dalam systems thinking agar dapat lebih memahami dan mengkomunikasikan suatu permasalahan (Anderson \& Johnson, 1997), yaitu: (1) Berfikir dengan gambaran besar ("Big Pictures"). Yang dimaksud dengan berfikir dengan gambaran besar yaitu dengan melihat dampak-dampak (efect) perubahan-perubahan sistem, karena permasalahan yang terjadi saat ini merupakan bagian dari sistem yang besar. Dalam menemukan sumber-sumber per- 
soalan yang muncul, harus memperluas penglihatan pada sistem besar. Dengan perspektif yang luas akan lebih mudah menemukan solusi yang efektif; (2) Menyeimbangkan perspektif jangka pendek dan jangka panjang. Systems thinking dapat memperlihatkan perilaku dimana kesuksesan jangka pendek akan memberi pengaruh negatif dalam jangka panjang. Akan tetapi bukan berarti juga melihat jangka pendek akan berpengaruh lebih baik dengan kondisi saat ini. Kuncinya adalah pusatkan perhatian pada dampak potensial dalam penentuan keputusan atau strategi yang dibuat; (3) Mengenali dinamika, komplek, dan kebergantungan (interdependent) alamiah suatu sistem. Saat melihat realitas dunia secara sistematis, akan nampak jelas segala sesuatu itu dinamis, komplek dan saling bergantung. Saat meragukan dapat memecahkan persoalan yang sangat besar dan ketidakpastian masa depan, cobalah mulai dari hal-hal sederhana. Systems thinking tidak menganjurkan untuk mengesampingkan semua permasalahan bersama-sama. Sebaliknya systems thinking mengingatkan untuk berawal dari hal-hal yang sederhana, struktur dan membatasi berfikir linier. Hal pokok yang ditekankan adalah semua sistem berhubungan dari dalam dan dari luar; (4) Mengumpulkan faktor-faktor yang terukur (measurable) dan tak terukur (non measurable). Nilai-nilai kuantitatif (terukur) dan tak terukur hanyalah suatu kebalikan saja, systems thinking menggunakan keduanya. Sebagai contoh yang terukur seperti biaya, penjualan, produksi, dan sebagainya, sedangkan contoh yang tidak terukur seperti moral, sikap, dan sebagainya, keduanya penting dan perlu untuk dipertimbangkan. Satu hal yang perlu diingat adalah systems thinking adalah tidak terfokus pada data yang terukur saja seperti data-data statistik, tetapi juga gejala lain yang bersifat tidak terukur.

Pendekatan berpikir sistem memiliki alat (tools) yang dikenal dengan nama sistem archetype yang berguna untuk mengenali pola tingkah laku sistem. Tiap archetype menggambarkan garis cerita dengan tema tersendiri, pola tingkah laku secara khusus dapat digambarkan dan struktur sistem yang unik dapat dilukiskan dengan diagram sebab akibat (causal loop diagram/ CLD). Keterkaitan antara berbagai unsur dari berbagai kriteria yang terdiri dari aspek teknis, aspek ekonomi, aspek sosial serta aspek regulasi dan kebijakan digambarkan dalam sebuah struktur yang di dalamnya dibangun menggunakan system archetype dalam CLD (causal loop diagram).

Sistem archetype ialah alat (tools) dari systems thinking yang berguna untuk mengenali pola tingkah laku sistem. Tiap archetype menggambarkan garis cerita dengan tema tersendiri, pola tingkah laku secara khusus dapat digambarkan dan struktur sistem yang unik dapat dilukiskan dengan diagram causal loop diagram.

Wolstenholme (2003), mengatakan bahwa setiap struktur terdiri atas aksi atau konsekuensi yang diharapkan (intended consequences) dan reaksi atau konsekuensi yang tidak diharapkan (unintended consequences) serta waktu tunda (delay) pada reaksi. Systems archetype dapat digunakan untuk membantu membangkitkan pemahaman serta aplikasinya pada berbagai bidang.

\section{Hasil dan Pembahasan}

\section{Analisis Sistem Hukum}

\section{a. Sistem Hukum Terkait Pembatasan Lahan Usaha Perkebunan}

Hukum merupakan sistem, artinya hukum merupakan tatanan dan merupakan suatu kesatuan yang utuh yang terdiri dari bagian-bagian atau unsur-unsur yang saling berkaitan erat satu sama lain. Dengan perkataan lain sistem hukum adalah suatu kesatuan yang terdiri dari unsur -unsur yang mempunyai interaksi satu sama lain dan bekerja sama untuk mencapai tujuan kesatuan tersebut. 
Kesatuan tersebut diterapkan terhadap kompleks unsur-unsur yuridis seperti peraturan hukum, asas hukum dan pengertian hukum.

Demikian halnya dengan Sistem Hukum Perkebunan. Sistem hukum perkebunan bukan merupakan sistem hukum yang berdiri sendiri namun berkaitan dengan sistem-sistem hukum yang lain (Gambar 1.). Dari pengertian dan Gambar 1. tersebut dapat dipahami bahwa sistem hukum perkebunan merupakan sistem yang terbuka. Artinya, sistem hukum ini merupakan kesatuan unsur-unsur (peraturan, penetapan) yang dipengaruhi faktor-faktor kebudayaan, sosial, ekonomi, sejarah dan sebagainya. Peraturan-peraturan hukum itu terbuka untuk penafsiran yang berbeda, oleh karena itu selalu terjadi perkembangan.

Perkebunan secara harfiah adalah segala kegiatan penqelolaan potensi perkebunan mulé

yang memiliki nilai tambah secara ekonomi dan berkelanjutan. Undang-undang No 39 Tahun 2014 tentang perkebunan, pada pasal 1 mendefiniskan perkebunan adalah segala kegiatan pengelolaan sumber daya alam, sarana produksi, alat dan mesin, budi data, panen, pengolahan, dan pemasaran terkait Tanaman Perkebunan.

Secara hierarki, sistem hukum perkebunan merupakan perkembangan dari sistem hukum agraria. Sistem hukum agraria adalah bagian dari sistem hukum benda yang merupakan bagian dari sistem hukum perdata. Oleh karenanya sistem hukum perkebunan tidak bisa dilepaskan dari hukum agraria dan tata ruang (Gambar 2.).Sistem hukum perkebunan ini pun erat kaitannya dengan hukum perusahaan, hukum investasi, hukum persaingan usaha serta peraturan perundanq-undangan tentanq perlindungan

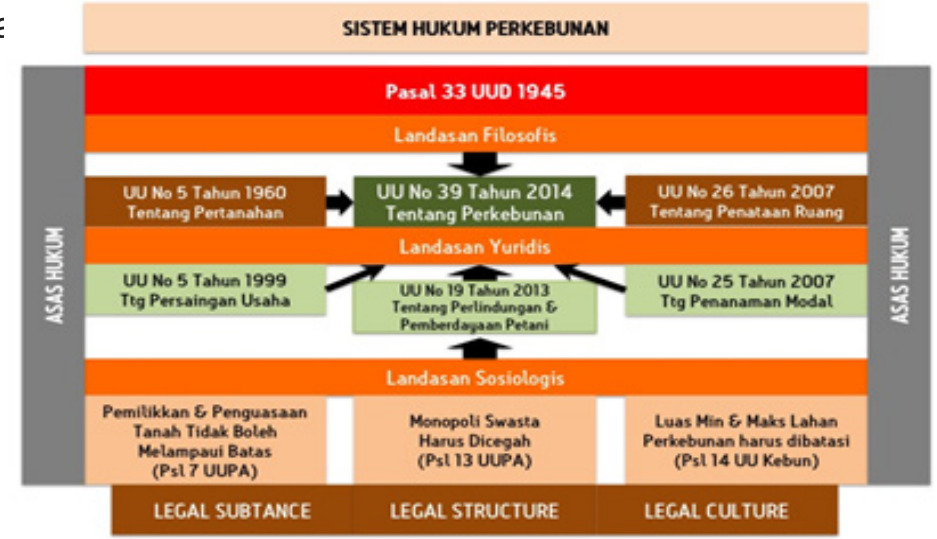

Gambar 1.

Sistem Hukum Perkebunan

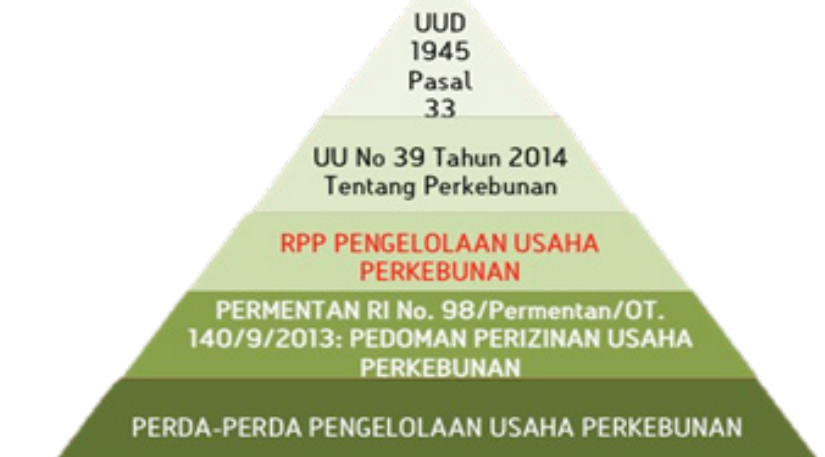

Gambar 2.

Hirarki Peraturan Tentang Perkebunan 


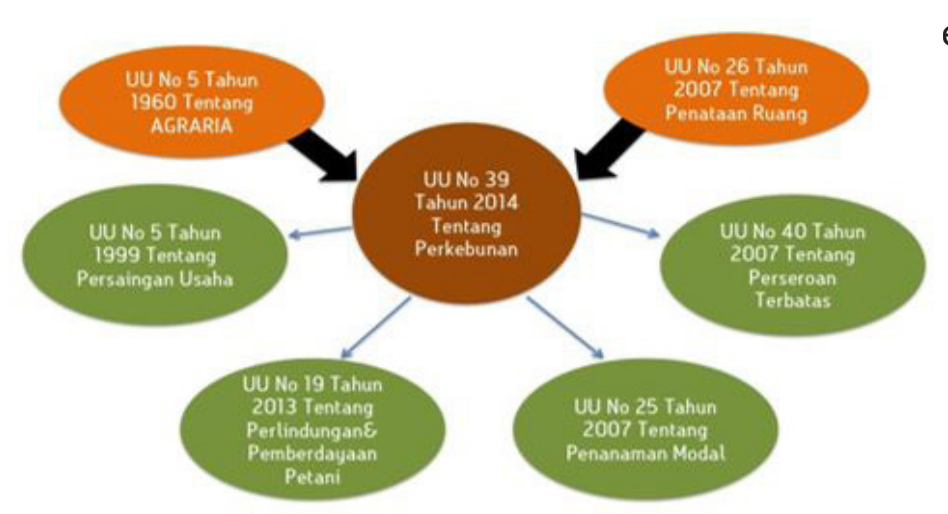

edar perbaikan,

Gambar 3.

Skema Konstruksi Hukum Perkebunan

\section{b. Sistem Hukum Perkebunan Peri- ode Indonesia Merdeka Sampai Tahun 1960}

Diproklamirkannya kemerdekaan Indonesia pada tanggal 17 Agustus 1945 mengakibatkan bangsa Indonesia memperoleh kedaulatan di tangan sendiri. Pada masa itu pendudukan tanah oleh masyarakat sudah menjadi hal yang sangat kompleks. Masyarakat yang belum berkesempatan menduduki tanah perkebunan, dalam waktu singkat berusaha untuk menduduki tanah tersebut. Selain itu, peraturan-peraturan hukum yang ditinggalkan penjajah Belanda masih membelenggu bangsa Indonesia. KUHPerdata yang berlaku di Indonesia merupakan politik hukum Belanda yang memberlakukan KUHPerdata yang berlaku di Belanda dengan beberapa perubahan berdasarkan asas konkordansi diberlakukan di Indonesia.

\section{c. Sistem Hukum Perkebunan Pasca UUPA 1960}

Lahirnya Undang-Undang Pokok Agraria (UUPA) di tahun 1960 merupakan peristiwa penting di bidang agraria dan pertanahan di Indonesia. Penghapusan kebijakan-kebijakan pertanahan ala pemerintah kolonial Belanda ditanggalkan satu persatu melalui lahirnya undang-undang tersebut. Pemerintah Orde lama dalam menetapkan UUPA sebagai hukum agraria nasional tetapi juga perombakan terhadap sendisendi hukum agraria kolonial sehingga UUPA memiliki substansi yang berbeda dan lebih sesuai dengan kepentingan dan nilai-nilai dari bangsa yang sudah merdeka. Proses yang demikian ini adalah wajar, mengingat hukum harus ditempatkan dalam konteks masyarakatnya. Hukum lahir dan dipengaruhi oleh situasi dan kondisi yang ada dalam masyarakat.

\section{d. Sistem Hukum Perkebunan dalam UU Nomor 39 Tahun 2014 Tentang Perkebunan}

Pemerintah RI telah mengundangkan Undang-Undang Nomor 39 Tahun 2014 tentang Perkebunan sebagai pengganti Undang-Undang No 18 Tahun 2004 pada tanggal 17 Oktober 2014 melalui Lembaran Negara Republik Indonesia Tahun 2014 Nomor 308, Tambahan Lembaran Negara Republik Indonesia Nomor 5613, selanjutnya disebut UU Perkebunan. UU Perkebunan tersebut mempunyai spirit utama untuk mewujudkan amanat Undang-Undang Dasar 1945. Hal tersebut ditunjukkan antara lain dengan pengaturan secara eksplisit maupun implisit mengenai keberpihakan kepada Masyarakat Perkebunan dan Masyarakat (Hukum) Adat; Kemitraan; Peran Serta Masyarakat; Mengutamakan Penggunaan Penanaman Modal Dalam Negeri. 
UU Perkebunan telah mengamanat kan beberapa ketentuan untuk diatur lebih lanjut dalam peraturan pelaksanaan, yaitu 21 (dua puluh satu) perihal yang akan diatur dalam Peraturan Pemerintah dan 12 (dua belas) perihal yang akan diatur dalam Peraturan Menteri. Berdasarkan ketentuan Pasal 117 UU Perkebunan, peraturan pelaksanaan tersebut harus ditetapkan paling lama 2 (dua) tahun sejak UU Perkebunan diundangkan.

Berdasarkan amanat UU tersebut terdapat beberapa peraturan pelaksanaan yang harus segera dibuatkan Peraturan Pemerintahnya, salah satunya adalah perihal penetapan batasan luas maksimum dan luas minimum penggunaan lahan untuk Usaha Perkebunan sebagaimana diamanatkan oleh Pasal 14 ayat 3. Oleh karena itu, pembuatan naskah akademik Peraturan Pemerintah ini harus selaras dengan konsepsi falsafah negara, tujuan nasional, UUD NRI Tahun 1945, UU Perkebunan dan undang-undang lain yang telah ada dan peraturan pelaksanaannya serta kebijakan lainnya yang terkait.

\section{Analisis Landasan Hukum}

\section{a. Landasan Filosofis}

Landasan filosofis merupakan pertimbangan atau alasan yang menggambarkan bahwa Rancangan Peraturan Pemerintah (RPP) Pengelolaan Usaha Perkebunan mempertimbangkan pandangan hidup, kesadaran, dan cita hukum yang meliputi suasana kebatinan serta falsafah bangsa Indonesia yang bersumber dari Pancasila dan Pembukaan Undang-Undang Dasar Negara RI Tahun 1945.

Berkaitan dengan itu maka yang menjadi landasan filosofis tersebut adalah Pasal 33 ayat $1,2,3$, 4, dan 5 Undangundang Dasar 1945. Dalam Pasal 33 UUD 1945 ini, memiliki makna bahwa kemakmuran rakyat-lah yang harus di utamakan, bukan kemakmuran seseorang atau sekelompok orang saja. Selanjutnya dikatakan bahwa "Bumi dan air dan kekayaan alam yang terkandung dalam bumi adalah pokok-pokok kemakmur- an rakyat. Sebab itu harus dikuasai oleh Negara dan dipergunakan untuk sebesar-besarnya kemakmuran rakyat".

Pasal 33 UUD 1945 menyebutkan bahwa sumber daya alam dikuasai negara dan dipergunakan sebesar-besarnya bagi kemakmuran rakyat. Dengan demikian, monopoli pengaturan, penyelengaraan, penggunaan, persediaan dan pemeliharaan sumber daya alam serta pengaturan hubungan hukumnya berada pada negara. Dengan kata lain, monopoli; oligopoli maupun praktek kartel dalam bidang pengelolaan sumber daya alam bertentangan dengan prinsip Pasal 33 UUD 1945.

Dalam Pasal 33 ini menjelaskan bahwa perekonomian Indonesia akan ditopang oleh 3 pelaku utama yaitu Koperasi, BUMN/D (Badan Usaha Milik Negara/Daerah), dan Swasta yang akan mewujudkan demokrasi ekonomi yang bercirikan mekanisme pasar, serta intervensi pemerintah, dan pengakuan terhadap hak milik perseorangan. Penafsiran dari kalimat "dikuasai oleh negara" dalam ayat 2 dan 3 tidak selalu dalam bentuk kepemilikan tetapi utamanya dalam bentuk kemampuan untuk melakukan kontrol dan pengaturan serta memberikan pengaruh agar perusahaan tetap berpegang pada asas kepentingan mayoritas masyarakat, dan sebesar-besarnya kemakmuran rakyat.

Hak Menguasai dari Negara/HMN dalam UUPA, khususnya pada pasal 2 ayat 2 (sebagaimana termaksud dalam pasal 2 ayat 1 UUPA) adalah memberi wewenang untuk: a) mengatur dan menyelenggarakan peruntukan; penggunaan; persediaan; dan pemeliharaan bumi; air; dan ruang angkasa tersebut, b) menentukan dan mengatur hubungan-hubungan hukum antara orang dengan bumi, air, dan ruang angkasa, c) menentukan dan mengatur hubungan- 
hubungan hukum antara orang-orang dan perbuatan-perbuatan hukum mengenai bumi, air, dan ruang angkasa.

\section{b. Landasan Sosiologis}

Rancangan Peraturan Pemerintah (RPP) Pengelolaan Usaha Perkebunan disusun dengan memperhatikan landasan sosiologis yang merupakan pertimbangan atau alasan yang menggambarkan adanya berbagai aspek kebutuhan masyarakat dan negara. Landasan sosiologis yang berkaitan dengan pembatasan luas maksimum penggunaan lahan untuk usaha perkebunan tersirat dalam Asas-asas Hukum, baik itu Asas Hukum Agraria maupun Asas Hukum Perkebunan, yaitu: Pertama, Asas Landreform (Pasal 7, 10 dan 17 UUPA) a) Pasal 7 UUPA: Untuk tidak merugikan kepentingan umum maka pemilikan dan penguasaan tanah yang melampaui batas tidak diperkenankan. b) Pasal 10 UUPA: 1) Setiap orang dan badan hukum yang mempunyai sesuatu hak atas tanah pertanian pada asasnya diwajibkan mengerjakan atau mengusahakannya sendiri secara aktif, dengan mencegah cara-cara pemerasan, 2) Pelaksanaan dari pada ketentuan dalam ayat 1 pasal ini akan diatur lebih lanjut dengan peraturan perundangan, 3) Pengecualian terhadap asas tersebut pada ayat 1 pasal ini diatur dalam peraturan perundangan. c) Pasal 17 UUPA: 1) Dengan mengingat ketentuan dalam pasal 7 maka untuk mencapai tujuan yang dimaksud dalam pasal 2 ayat 3 diatur luas maksimum dan/atau minimum tanah yang boleh dipunyai dengan sesuatu hak tersebut dalam pasal 16 oleh satu keluarga atau badan hukum, 2) Penetapan batas maksimum termaksud dalam ayat 1 dari pasal ini dilakukan dengan peraturan perundangan didalam waktu yang singkat, 3) Tanah-tanah yang merupakan kelebihan dari batas maksimum termaksud dalam ayat 2 pasal ini diambil oleh Pemerintah dengan ganti kerugian, untuk selanjutnya dibagikan kepada rakyat yang membutuh- kan menurut ketentuan-ketentuan dalam Peraturan Pemerintah, 4) Tercapainya batas minimum termaksud dalam ayat 1 dari pasal ini, yang akan ditetapkan dengan peraturan perundangan, dilaksanakan secara berangsur-angsur.

Kedua, Asas Tata Guna Tanah (pasal 13, 14 dan 15 UUPA); Pasal 13 UUPA: 1) Pemerintah berusaha agar supaya usaha-usaha dalam lapangan agraria diatur sedemikian rupa, sehingga meninggikan produksi dan kemakmuran rakyat sebagai yang dimaksud dalam pasal 2 ayat 3 serta menjamin bagi setiap warga negara Indonesia derajat hidup yang sesuai dengan martabat manusia, baik bagi diri sendiri maupun keluarganya, 2) Pemerintah mencegah adanya usaha-usaha dalam lapangan agraria dari organisasi-organisasi dan perseorangan yang bersifat monopoli swasta, 3) Usahausaha Pemerintah dalam lapangan agraria yang bersifat monopoli hanya dapat diselenggarakan dengan Undang-undang, 4) Pemerintah berusaha untuk memajukan kepastian dan jaminan sosial, termasuk bidang perburuhan, dalam usaha-usaha dilapangan agraria.

Berkaitan dengan pengecualian pada Pasal 10 ayat 3 diatas, telah diatur dalam Pasal 51 Undang Undang No 5 Tahun 1999 (UU tentang Larangan Monopoli dan Persaingan Tidak Sehat) yang berbunyi : "Monopoli dan atau pemusatan kegiatan yang berkaitan dengan produksi dan atau pemasaran barang dan atau jasa yang menguasai hajat hidup orang banyak serta cabang-cabang produksi yang penting bagi negara diatur dengan undang-undang dan diselenggarakan oleh Badan Usaha Milik Negara dan atau badan atau lembaga yang dibentuk atau ditunjuk oleh Pemerintah."

Cabang produksi yang menguasai hajat hidup orang banyak dibagi ke dalam tiga kategori. Pertama terkait alokasi, yaitu barang atau jasa yang berasal dari sumber daya alam. Kedua terkait distribusi, yakni 
kebutuhan pokok masyarakat, tapi suatu waktu atau terus menerus tidak dapat dipenuhi pasar. Ketiga terkait stabilisasi seperti pertahanan keamanan, moneter, fiskal dan regulasi.

Ketiga, Asas Kebermanfaatan dan Berkeadilan dalam Undang-Undang Perkebunan Pasal 14; 1) Pemerintah Pusat menetapkan batasan luas maksimum dan luas minimum penggunaan lahan untuk Usaha Perkebunan, 2) Penetapan batasan luas sebagaimana dimaksud pada ayat 1 harus mempertimbangkan: a. jenis tanaman; b. ketersediaan lahan yang sesuai secara agroklimat; c. modal; d. kapasitas pabrik; e. tingkat kepadatan penduduk; f. pola pengembangan usaha; g. kondisi geografis; h. perkembangan teknologi; dan i. pemanfaatan lahan berdasarkan fungsi ruang sesuai dengan ketentuan peraturan perundang-undangan di bidang tata ruang, 3) Ketentuan lebih lanjut mengenai penetapan batasan luas diatur dalam Peraturan Pemerintah.

Keempat, Asas-asas yang berkaitan dengan "kewenangan" membuat pengaturan luas maksimum penggunaan lahan untuk Usaha Perkebunan diatur sebagai Hak Menguasai dari Negara/HMN dalam UUPA: pasal 2 ayat 2 (sebagaimana termaktub dalam pasal 2 ayat 1 UUPA) adalah wewenang: a) mengatur dan menyelenggarakan peruntukan; penggunaan; persediaan; dan pemeliharaan bumi; air; dan ruang angkasa tersebut, b) menentukan dan mengatur hubungan-hubungan hukum antara orang dengan bumi, air, dan ruang angkasa, c) menentukan mengatur hubunganhubungan hukum antara orang-orang dan perbuatan-perbuatan hukum yang mengenai bumi, air, dan ruang angkasa.

Kelima, Berbagai peraturan dan perundang-undangan yang tujuannya sejalan dengan pengaturan luas maksimum penggunaan lahan untuk Usaha Perkebunan adalah: 1) UU RI Nomor 19 Tahun 2013 tentang Perlindungan dan
Pemberdayaan Petani, dalam pasal 7 ayat 3: strategi pemberdayaan petani dilakukan melalui konsolidasi dan jaminan luasan lahan pertanian, pasal 60 (pemberian lahan pertanian terutama kepada petani setempat yang: a. tidak memiliki lahan, b. memiliki lahan pertanian kurang dari 2 (dua) hektar, 2) UU RI Nomor 25 Tahun 2007 tentang Penanaman Modal, dalam: pasal 4 ayat 2 dan pasal 13 (perlunya prioritas kesempatan dan perlindungan UMKM serta pencadangan untuk UMKM), 3) UU Nomor 5 Tahun 1999 tentang UU Larangan Praktek Monopoli dan Persaingan Usaha Tidak Sehat, dalam Pasal 27: 1 (satu) pelaku usaha/kelompok pelaku usaha menguasai lebih dari 50\%, 2 - 3 pelaku usaha/kelompok pelaku usaha menguasai lebih dari $75 \%$ pangsa pasar satu jenis barang atau jasa tertentu. Namun demikian, meskipun peraturan ini sama-sama memiliki landasan filosofis pembatasan tetapi implementasi peraturan ini tidak cocok untuk pembatasan luas maksimum penggunaan lahan pada usaha perkebunan karena batasan $50 \%$ dan/atau $75 \%$ tersebut terlalu besar untuk penguasaan sumberdaya alam yang merupakan hajat hidup orang banyak, 4) PP RI Nomor 40 Tahun 1996 tentang HGU, HGB dan Hak Pakai Atas Tanah dalam pasal 5 ayat 2: Luas maksimum HGU untuk Badan Hukum ditetapkan oleh Menteri dengan pertimbangan satuan usaha paling berdayaguna, 5) Peraturan Menteri Agraria dan Tata Ruang/Kepala Badan Pertanahan Nasional Nomor 5 tahun 2015 tentang Izin Lokasi untuk usaha perkebunan yang diusahakan dalam bentuk perkebunan besar dengan diberikan HGU.

Untuk point 3) dan point 5), meskipun secara yuridis sejalan dengan pengaturan batasan luas maksimum penggunaan lahan untuk Usaha Perkebunan tetapi masih diperlukan harmonisasi hukum. Berkaitan dengan pengaturan penguasaan atas produksi sumber daya alam khususnya perkebunan sebaiknya 
perlu diatur lebih lanjut dalam UndangUndang LPM agar dapat memenuhi asas keadilan.

\section{c. Landasan Yuridis}

Selain harus memperhatikan landasan filosofis dan sosiologis, Rancangan Peraturan Pemerintah (RPP) Pengelolaan Usaha Perkebunan yang berkaitan dengan pengaturan pembatasan luas maksimum penggunaan lahan untuk usaha perkebunan juga harus memperhatikan landasan yuridis, yaitu pertimbangan atau alasan yang menggambarkan bahwa pembatasan luas maksimum penggunaan lahan ini disusun untuk mengatasi permasalahan hukum atau mengisi kekosongan hukum dengan mempertimbangkan aturan yang telah ada, yang akan diubah, atau yang akan dicabut guna menjamin kepastian hukum dan rasa keadilan masyarakat.

Berkaitan dengan Permentan Nomor 98 Tahun 2013 tentang Pedoman Perizinan Usaha Perkebunan tetap mengikat, sebelum RPP yang memuat Pembatasan tersebut disahkan dan berlaku. Hal ini ditegaskan dalam Pasal 8 ayat (2) UU No. 12/2011 yang menyebutkan: "Peraturan Perundang-undangan sebagaimana dimaksud pada ayat (1) diakui keberadaannya dan mempunyai kekuatan hukum mengikat sepanjang: 1) diperintahkan oleh Peraturan Perundang-undangan yang lebih tinggi, atau 2) dibentuk berdasarkan kewenangan."

Lebih lanjut, landasan yuridis menyangkut persoalan hukum terkait pembatasan dimaksud adalah persoalan Hak Guna Usaha (HGU) untuk Usaha Perkebunan: Subjek HGU, Objek HGU, Jangka Waktu HGU, Hapusnya HGU, Pemberian Hak HGU. Hal ini terjadi karena untuk menyelenggarakan usaha perkebunan izin usaha dan HGU Perkebunan diperlukan bersamaan dan proses untuk mendapatkannya saling berkaitan (Lampiran 4). Oleh karena itu, dalam penyelenggaraan usaha perkebunan diperlukan harmonsasi hukum antara perizinan usaha perkebunan dan HGU. Persoalan hukum lainnya yang terkait pembatasan dimaksud adalah: Afiliasi, Persaingan Usaha Tidak Sehat, dan Perusahaan Go Public.

\section{Ketimpangan Penguasaan Lahan pada Usaha Perkebunan}

Berdasarkan pelaku usahanya, perkebunan dapat dibagi menjadi Perkebunan Rakyat yang dikelola oleh para petani atau yang sering disebut pekebun dan oleh para pengusaha, baik dalam bentuk Perusahaan Besar Perkebunan Negara maupun Perusahaan Besar Perkebunan Swasta (Swasta Nasional dan Swasta Asing). Struktur penguasaan lahan pada usaha perkebunan, berbeda antar komoditas perkebunan. Diantara 11 komoditas unggulan strategis nasional perkebunan, hanya komoditas kelapa sawit dan teh yang penguasaan lahannya didominasi oleh perusahaan, sedangkan komoditas unggulan perkebunan lainnya didominasi oleh perkebunan rakyat.

Data Statistik Perkebunan 20152017, sebagaimana tertera pada Tabel 4, menunjukkan bahwa pada usaha kebun kelapa sawit, penguasaan lahan didominasi oleh perkebunan besar, masing-masing $59,7 \%$. Selain itu, pada usaha kelapa sawit, penguasaan lahan oleh perusahaan swasta jauh lebih dominan dari pada perusahaan negara, yaitu masing-masing $53,1 \%$ dan $6,6 \%$. Berdasarkan data Ditjenbun dan BKPM (Ditjenbun, 2016), pada tahun 2015 luas lahan kelapa sawit yang dikuasai perusahaan PMA mencapai 2,1 juta hektar atau setara degan $18,15 \%$ total lahan kelapa sawit Indonesia (sama dengan 31\% lahan kelapa sawit yang dikelola perusahaan) Untuk komoditas kelapa sawit, meskipun koorporasi lebih dominan dalam penguasaan lahan tetapi secara nominal jumlah lahan kelapa sawit yang dikuasai pekebun masih lebih besar dibanding luas lahan yang dikuasai pekebun untuk masing-masing komoditas unggulan strategis 
nasional lainnya. Gambar 6. dan Tabel 4 menunjukkan bahwa luas lahan perkebunan kelapa sawit rakyat mencapai 4,54 juta hektar atau 29,16\% dari total lahan yang digunakan untuk 11 komoditas perkebunan rakyat unggulan strategis nasional $(15,55$ juta hektar).

Sementara itu, pada tahun 2015 jumlah pekebun terbanyak adalah mereka yang mengusahakan komoditas kelapa, yaitu mencapai 6,6 juta kepala keluarga (KK) atau $37,31 \%$ dari total pekebun yang mengusahakan 11 komoditas unggulan strategis nasional perkebunan yang jumlahnya mencapai 17,4 juta KK (Gambar 7). Meskipun pada tahun 2015 total luas lahan yang diusahakan oleh pekebun kelapa sawit paling besar, tetapi jumlah pekebun yang mengelola komoditas kelapa sawit hanya 2,2 juta kepala keluarga atau $12,32 \%$ dari total jumlah pekebun yang mengusahakan 11 komoditas unggulan strategis nasional perkebunan. Tabel 4.

Struktur Makro (Nasional) Penguasaan Lahan pada Usaha Komoditas Unggulan Strategis Nasional Perkebunan

\begin{tabular}{|c|c|c|c|c|c|c|c|}
\hline \multirow[t]{2}{*}{ Tanaman } & \multirow{2}{*}{$\begin{array}{l}\text { Luas dan } \\
\text { Proporsi }\end{array}$} & \multirow[t]{2}{*}{ PR } & \multicolumn{3}{|c|}{ Perkebunan Besar/Korporasi } & \multirow{2}{*}{$\begin{array}{l}\text { Jumlah } \\
\text { PR + PB }\end{array}$} & \multirow{2}{*}{$\begin{array}{l}\% \text { thd } \\
\text { Total }\end{array}$} \\
\hline & & & PBN & PBS & $\begin{array}{c}\mathrm{PBN}+\mathrm{PB} \\
\mathrm{S}\end{array}$ & & \\
\hline \multirow[t]{2}{*}{ Sawit } & Luas (ha) & 4.535 .400 & 743.894 & 5.980 .982 & 6.724 .876 & 11.260 .276 & 48,52 \\
\hline & Proporsi (\%) & 40,3 & 6,6 & 53,1 & 59,7 & 100,0 & \\
\hline \multirow[t]{2}{*}{ Total } & Luas (ha) & 15.553 .081 & 1.117 .677 & 6.536 .832 & 7.654 .509 & 23.207 .590 & 100,00 \\
\hline & Proporsi (\%) & 67,0 & 4,8 & 28,2 & 33,0 & 100,0 & \\
\hline
\end{tabular}

Sumber Data: Statistik Perkebunan 2015-2017 (Diolah)

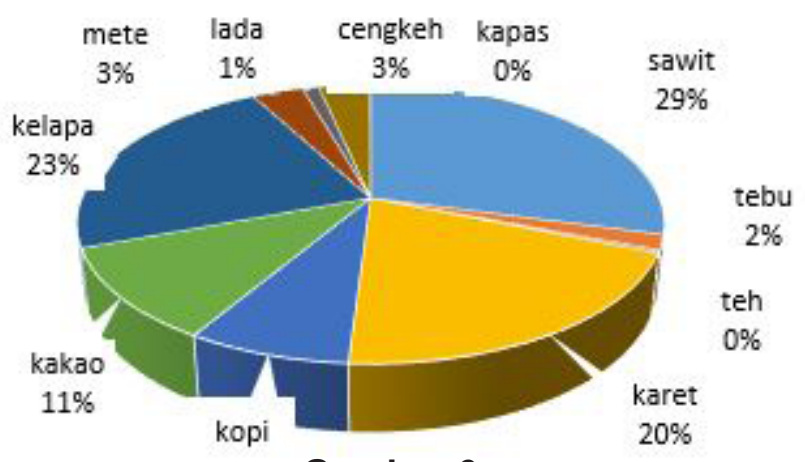

Gambar 6

Proporsi Luas Kebun Rakyat berdasarkan Komoditas Unggulan Perkebunan pada Tahun 2015 
Aspek Hukum dan....... MediaTrend 13 (1) 2018 p.1-30

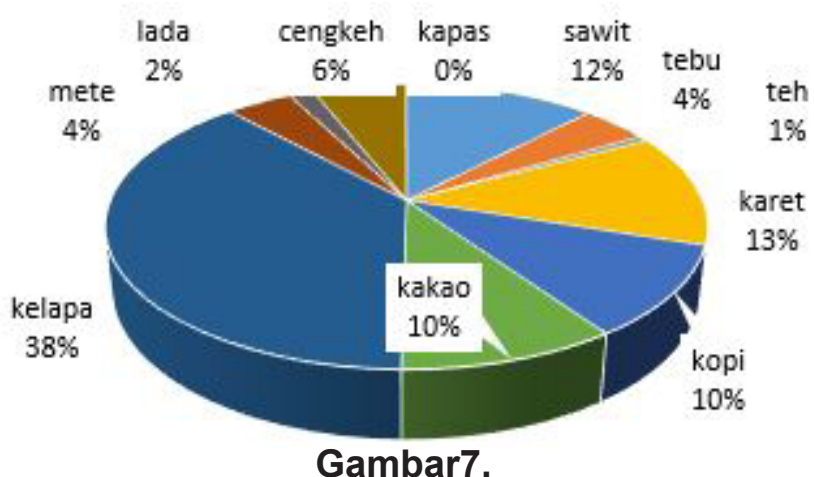

Proporsi Jumlah Pekebun berdasarkan Komoditas

Unggulan Perkebunan pada Tahun 2015

Sementara itu, pada 10 komoditas unggulan strategis nasional perkebunan lainnya struktur penguasaan lahan diantara para pelaku usaha masih berada pada kategori "ketimpangan rendah". Walaupun demikian, untuk usaha perkebunan teh, meskipun ketimpangan penguasaan lahan hanya berada pada kategori rendah tetapi nilainya mendekati nilai untuk kategori ketimpangan sedang (18,8\%). Artinya, $40 \%$ pelaku usaha teh/ pekebun $(45.367$ keluarga) hanya menguasai 18,8\% (22.459 hektar) dari total luas lahan perkebunan teh yang diusahakan oleh seluruh pelaku usaha.
Selain terjadi pada aras makro (nasional), ketimpangan penguasaan lahan pada usaha perkebunan juga dapat terjadi pada aras mikro (komunitas atau desa). Hasil penelitian yang dilakukan PT Riset Perkebunan Nusantara (Tabel 6) dalam Fadjar, 2009 dan Fadjar, 2010, ketimpangan dengan kategori rendah; sedang atau tinggi dapat terjadi dalam pengusaan lahan untuk usaha berbagai komoditas. Pada aras mikro, aksesibitas masyarakat terhadap lokasi perkotaan; program, dan sumber pendanaan untuk investasi serta tingginya jumlah pendatang lebih menonjol sebagai penyebab terjadinya ketimpangan penguasaan lahan untuk usaha perkebunan.

Tabel 5.

Ketimpangan Penguasaan Lahan pada Usaha Perkebunan

\begin{tabular}{|c|c|c|c|c|c|c|c|c|c|}
\hline \multirow[t]{2}{*}{ Komoditas } & \multicolumn{2}{|c|}{ PR } & \multicolumn{2}{|c|}{ PB } & \multirow{2}{*}{$\begin{array}{c}\text { Total } \\
\text { Pelaku } \\
\text { (PR+PB) }\end{array}$} & \multicolumn{4}{|c|}{$40 \%$ Pelaku } \\
\hline & $\begin{array}{c}\text { Luas PR } \\
\text { (Ha) }\end{array}$ & $\begin{array}{l}\text { Jumlah } \\
\text { Pekebun } \\
\text { (KK) }\end{array}$ & $\begin{array}{c}\text { Luas PB } \\
(\mathrm{Ha})\end{array}$ & $\begin{array}{c}\text { Jumlah } \\
\text { Pelaku } \\
\text { PB }\end{array}$ & & $\begin{array}{l}\text { Jumlah } \\
\text { Pelaku }\end{array}$ & $\begin{array}{l}\text { Luas } \\
\text { (ha) }\end{array}$ & $\begin{array}{c}\text { \%Lahan } \\
\text { Thd } \\
\text { Total }\end{array}$ & $\begin{array}{c}\text { Tingkat } \\
\text { Ketimpangan }\end{array}$ \\
\hline sawit & 4.422 .365 & 2.052 .050 & 6.725 .269 & 1.601 & 2.053 .651 & 821.460 & 1.755 .563 & 15,7 & sedang \\
\hline tebu & 290.967 & 794.513 & 187.142 & 99 & 794.612 & 317.845 & 117.070 & 24,5 & rendah \\
\hline teh & 53.359 & 113.304 & 65.943 & 114 & 113.418 & 45.367 & 22.459 & 18,8 & rendah \\
\hline karet & 3.067 .388 & 2.194 .486 & 538.857 & 332 & 2.194 .818 & 877.927 & 1.225 .894 & 34,0 & rendah \\
\hline kopi & 1.183 .663 & 1.765 .401 & 46.831 & 98 & 1.765 .499 & 706.200 & 467.172 & 38,0 & rendah \\
\hline kakao & 1.686 .178 & 1.732 .355 & 41.259 & 87 & 1.732 .442 & 692.977 & 676.277 & 39,1 & rendah \\
\hline kelapa & 3.570 .933 & 6.622 .868 & 38.879 & 111 & 6.622 .979 & 2.649 .192 & 1.443 .333 & 40,0 & rendah \\
\hline mete & 529.809 & 763.183 & 1.344 & n.a & 763.183 & 305.273 & 211.924 & 39,9 & rendah \\
\hline lada & 162.603 & 279.026 & 0 & n.a & 279.026 & 111.610 & 64.952 & 39,9 & rendah \\
\hline cengkeh & 501.028 & 1.012 .298 & 9.147 & 52 & 1.012 .350 & 404.940 & 199.778 & 39,2 & rendah \\
\hline kapas & 3.670 & 6.125 & 0 & n.a & 6.125 & 2.450 & 1.948 & 53,1 & rendah \\
\hline Jumlah & 15.471 .963 & 17.335 .609 & 7.654 .675 & n.a & 17.335 .609 & 6.934 .244 & 6.236 .574 & 27,0 & rendah \\
\hline Sawit 2045 & 11.824 .615 & 5.630 .769 & 6.725 .269 & 1.601 & 5.632 .370 & 2.252 .948 & 4.814 .831 & 26,0 & rendah \\
\hline
\end{tabular}

Sumber Data: Statistik Perkebunan 2015-2017 (Diolah) 
Tabel 6.

Ketimpangan Pemilikan Lahan Usaha Perkebunan pada Aras Komunitas/Desa

\begin{tabular}{clcc}
\hline Jenis Tanaman & \multicolumn{1}{c}{ Komunitas/Desa } & Gini Ratio & Kategori \\
\hline \multirow{2}{*}{ Kelapa Sawit } & Lokal + Pendatang-Kampar & 0,77 & $\mathrm{~T}$ \\
& PIR-BUN-Kampar & 0,21 & $\mathrm{R}$ \\
\hline \multirow{3}{*}{ Kakao } & Lokal jauh dari Kota - Pidie & 0,32 & $\mathrm{R}$ \\
& Lokal dekat Kota - Pidie & 0,57 & $\mathrm{~T}$ \\
& Lokal - Donggala & 0,44 & $\mathrm{M}$ \\
& Pendatang - Donggala & 0,69 & $\mathrm{~T}$ \\
\hline \multirow{3}{*}{ Karet } & Lokal-Banyuasin & 0,30 & $\mathrm{R}$ \\
& PIR-BUN-Banyuasin & 0,70 & $\mathrm{~T}$ \\
& Lokal - Danau Salak & 0,29 & $\mathrm{R}$ \\
\hline Tebu & PIR-BUN - Danau Salak & 0,48 & $\mathrm{M}$ \\
\hline
\end{tabular}

Sumber Data: Hasil Riset PT RPN

Keterangan: $<0,4=\operatorname{Rendah}(\mathrm{R}), 0,4-0,5=$ Moderat $(\mathrm{M}),>0,5=$ Tinggi $(\mathrm{T})$

Hasil kajian PT RPN (Fadjar, 2009 dan Fadjar, 2010) lainnya sebagaimana tertera pada Tabel 7., menunjukkan bahwa sebaran pekebun berdasarkan luas lahan yang mereka miliki berbeda antar komoditas yang satu dengan yang lainnya. Pada usaha perkebunan kelapa sawit yang memerlukan kemampuan finansial relatif besar baik untuk investasi pembangunan kebun maupun biaya pemeliharaan, proporsi terbesar pekebun berada pada kategori pemilikan lahan dengan luas $2-<3$ ha $(44,61 \%)$, kemudian proporsi menengah berada pada kategori pekebun dengan luas pemilikan lahan cukup tinggi atau $>4$ hektar $(21,81 \%)$ dan pada kelompok pekebun yang tidak memiliki lahan atau buruh tani $(28,9 \%)$.
Dalam hal ini nampak struktur penguasaan lahan pada komunitas pekebun kelapa sawit cenderung terpolarisasi. Sementara itu, pada usaha perkebunan kakao yang memerlukan kemampuan finansial relatif relatif kecil dibanding untuk usaha kebun sawit, proporsi terbesar pekebun $(55,80 \%)$ berada pada kategori pemilikan lahan dengan luas $>0-<2$ hektar, kemudian pekebun lainnya relatif menyebar pada kategori-kategori lainnya. Dalam hal ini struktur penguasaan lahan pada komunitas pekebun kakao cenderung terstratifikasi.

Sejalan dengan itu, pada tahun 2015, sebagian besar tenaga kerja perusahaan yang mengelola komoditas unggu

Tabel 7.

Distribusi Pemilikan Lahan Usaha Perkebunan pada Aras Komunitas/Desa

\begin{tabular}{ccc}
\hline Luas Pemilikan (Ha) & Kelapa Sawit (\%) & Kakao (\%) \\
\hline 0 & $\mathbf{2 8 , 1 9}$ & 12,00 \\
$>0-<2$ & 2,45 & $\mathbf{5 5 , 8 0}$ \\
$2-<3$ & $\mathbf{4 4 , 6 1}$ & 19,40 \\
$3-<4$ & 2,94 & 6,60 \\
$>/ 4$ & $\mathbf{2 1 , 8 1}$ & 6,20 \\
Total & $\mathbf{1 0 0 , 0 0}$ & $\mathbf{1 0 0 , 0 0}$ \\
\hline Rata-rata & $\mathbf{2 , 2 8}$ & $\mathbf{1 , 6 3}$ \\
\hline Tertinggi (ha) & $\mathbf{4 2 , 0 0}$ & $\mathbf{2 8 , 0 0}$ \\
\hline
\end{tabular}

Sumber Data: Hasil Riset PT RPN. Diolah. 
Tabel 8.

Jumlah Pekebun dan Jumlah Tenaga Kerja pada Perusahaan Perkebunan

\begin{tabular}{lrrrrrr}
\hline \multicolumn{1}{c}{ Komoditas } & \multicolumn{2}{c}{ Petani } & \multicolumn{1}{c}{ TK } & \multicolumn{2}{c}{ Jumlah } \\
\cline { 2 - 7 } Sawit & \multicolumn{1}{c}{ KK } & \multicolumn{1}{c}{$\%$} & \multicolumn{1}{c}{ Orang } & \multicolumn{1}{c}{$\%$} & \multicolumn{1}{c}{ KK } & \multicolumn{1}{c}{ \% } \\
Tebu & 715.434 & 12,22 & 3.367 .495 & 81,82 & 5.482 .929 & 25,59 \\
Teh & 745.229 & 4,30 & 271.572 & 6,60 & 1.016 .801 & 4,75 \\
Karet & 113.260 & 0,65 & 97.591 & 2,37 & 210.851 & 0,98 \\
Kopi & 2.221 .269 & 12,83 & 243.273 & 5,91 & 2.464 .542 & 11,50 \\
Kakao & 1.785 .940 & 10,32 & 62.794 & 1,53 & 1.848 .734 & 8,63 \\
Kelapa & 1.715 .155 & 9,91 & 35.097 & 0,85 & 1.750 .252 & 8,17 \\
Mete & 6.563 .526 & 37,91 & 17.290 & 0,42 & 6.580 .816 & 30,71 \\
Lada & 735.161 & 4,25 & 341 & 0,01 & 735.502 & 3,43 \\
Cengkeh & 273.556 & 1,58 & 14 & 0,00 & 273.570 & 1,28 \\
Kapas & 1.036 .052 & 5,98 & 20.381 & 0,50 & 1.056 .433 & 4,93 \\
\hline Jumlah & 7.729 & 0,04 & - & - & 7.729 & 0,04 \\
\hline
\end{tabular}

Sumber Data: Hasil Riset PT RPN. Diolah.

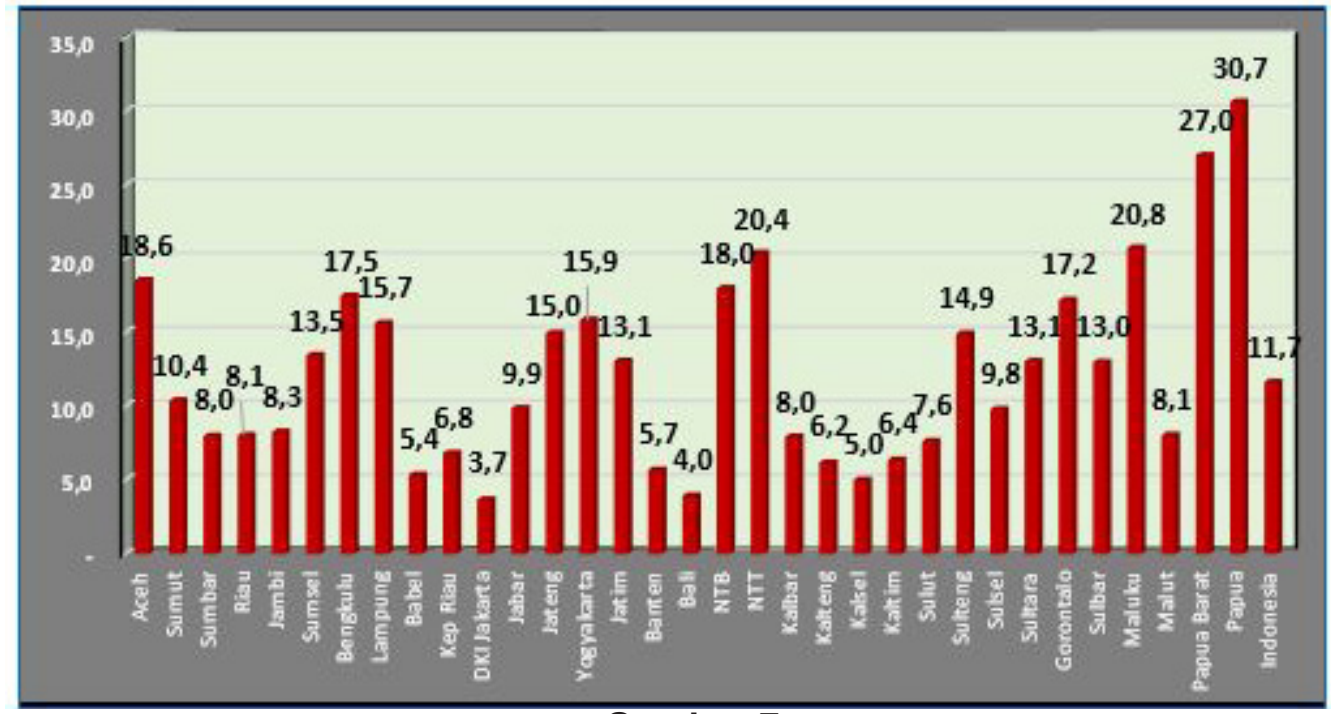

Gambar 7.

Proporsi Penduduk Miskin di Setiap Provinsi (\%) Tahun 2015

lan strategis nasional perkebunan bekerja pada perusahaan yang mengelola komoditas kelapa sawit, yaitu sebanyak 3,37 juta orang atau $81,82 \%$ dari jumlah tenaga yang bekerja pada perusahaan perkebunan komoditas unggulan strategis nasional yang mencapai 4,12 juta orang (Tabel 8 )

Lebih lanjut bila pekebun dan pekerja mewakili sebuah keluarga, maka jumlah keluarga di Indonesia yang mengandalkan pendapatannya dari peluang berusaha atau bekerja pada komoditas unggulan per- kebunan mencapai 21,43 juta keluarga. Hal ini juga berarti bahwa pada tahun 2015 jumlah penduduk Indonesia yang sumber kesejahteraannya tergantung pada peluang berusaha/bekerja dari 11 komoditas unggulan strategis nasional perkebunan secara langsung (kegiatan di kebun) mencapai 83,57 juta jiwa. Jumlah tersebut sama dengan $32,5 \%$ dari penduduk Indonesia atau $69,6 \%$ dari penduduk Indonesia yang bertempat tinggal di wilayah pedesaan. 


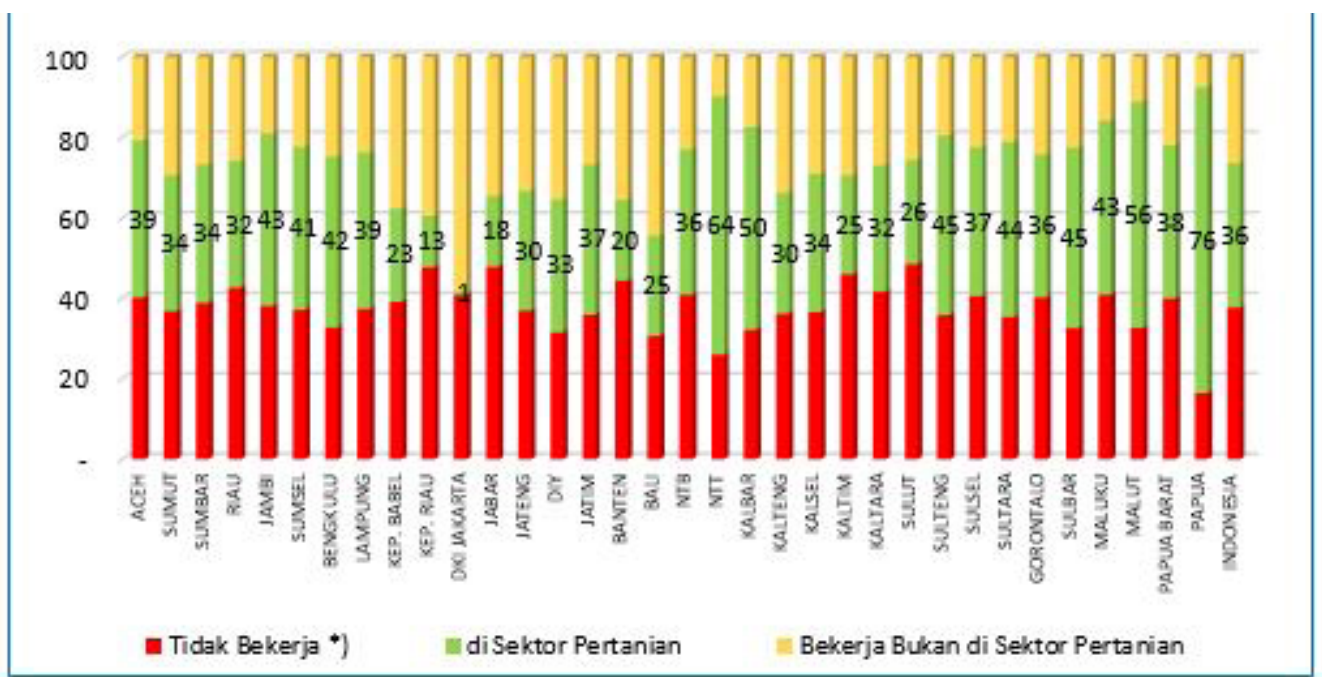

Gambar 8.

Proporsi Penduduk Miskin pada setiap Sektor di Setiap Provinsi (\%) Tahun 2015

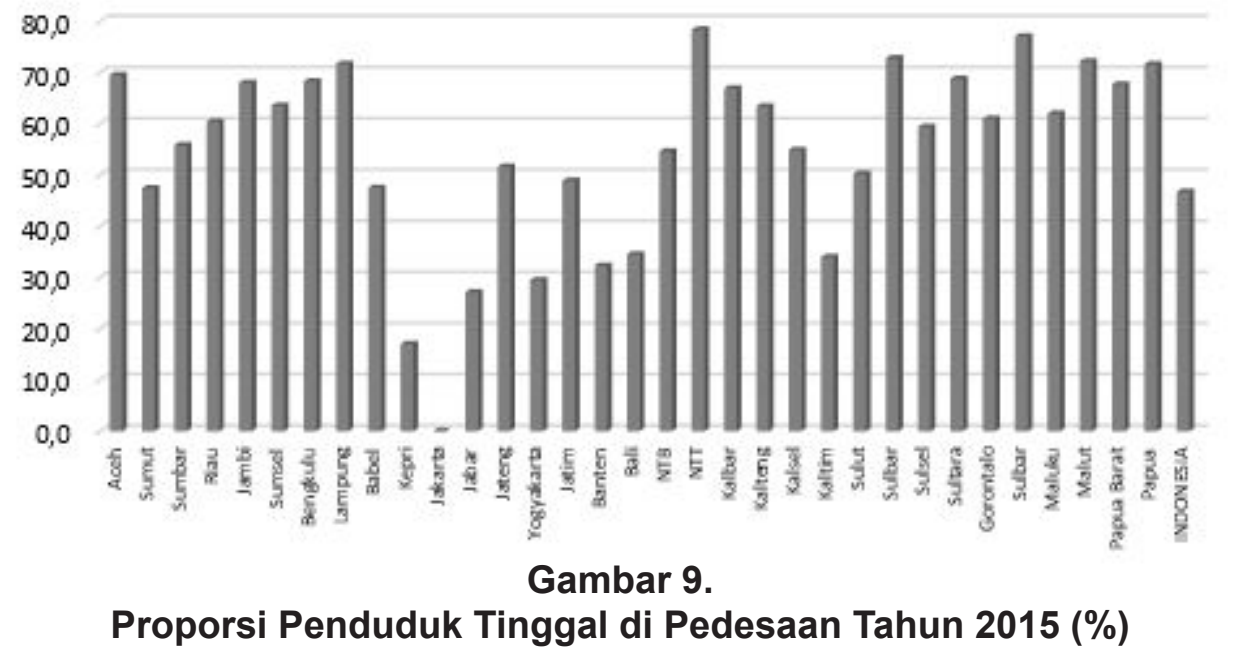

Selain itu, sebagaimana ditunjukkan pada Gambar 7, jumlah penduduk miskin di Indonesia masih cukup tinggi, termasuk di provinsi-provinsi di luar Jawa yang memiliki peluang berusaha/ bekerja pada sub sektor perkebunan relatif dominan. Misalnya, di provinsi-provinsi yang berada di pulau Sumatera; Kalimantan dan Sulawesi.

Gambaran tersebut diperkuat oleh data yang tersedia pada Gambar 8. yang menunjukkan bahwa sebagian penduduk miskin tersebut adalah penduduk yang

bekerja di sektor pertanian. Oleh sebab itu sub sektor perkebunan di masa yang akan datang akan tetap menjadi salah satu solusi penting dalam penyediaan lapangan usaha/bekerja dan dalam mengatasi kemiskinan penduduk Indonesia. Apalagi sebagian besar penduduk di sebagian besar provinsi masih bertempat tinggal di wilayah pedesaan (Gambar 9.) yang tentunya usaha-usaha yang berbasiskan sumber daya lahan seperti perkebunan akan menjadi pilihan utama. 


\section{Konflik pada Usaha Perkebunan}

Data yang dikumpulkan Direktorat Jenderal Perkebunan menunjukkan bahwa frekuensi atau intensitas terjadinya konflik atau Gangguan Usaha Perkebunan (GUP) ternyata cukup tinggi, dan konflik atau gangguan tersebut terus berlanjut dari tahun ke tahun. Gangguan Usaha Perkebunan tersebut dikelompokan menjadi: 1) konflik lahan (sengketa penguasaan lahan; ganti rugi lahan/tanam tumbuh), 2) konflik non lahan (tumpang tindih Izin Usaha Perkebunan/IUP; tuntutan fasilitasi pembangunan kebun masyarakat sekitar sebesar $20 \%$ dari HGU); penetapan harga panen; ingkar janji kemitraan; dan pencurian produksi, serta 3) konflik kehutanan (perubahan status kawasan hutan).

Data pada Tabel 9 menunjukkan bahwa dalam kurun waktu 4 (empat) tahun terakhir (2012 - 2015) ternyata gangguan usaha perkebunan yang paling banyak terjadi adalah konflik lahan $(71,6 \%)$, kemudian disusul konflik non lahan (24\%), sedangkan konflik kehutanan relatif sedikit $(3,8 \%)$. Dengan semakin dominannya penguasaan lahan usaha perkebunan oleh perusahaan (apalagi Perusahaan PMA) dikhawatirkan sentimen negatif terhadap perusahaan perkebunan semakin meningkat akibat ketimpangan yang disertai kemiskinan masyarakat. Kondisi ini jika dibiarkan dapat memicu semakin meningkatnya gangguan terhadap usaha perkebunan.
Berbagai hasil penelitian PT RPN menunjukkan bahwa gangguan usaha perkebunan yang terjadi di kebun dapat berupa pendudukan lahan; pencurian hasil; pengrusakan tanaman (ditebang, diracun agar mati, atau dibakar); dan pengrusakan kantor. Pada perkebunan karet pencurian hasil selain menyebabkan perusahaan kehilangan pendapatan harian juga menyebabkan umur ekonomis tanaman berkurang separuhnya karena kulit tanaman rusak akibat penyadapan berat. Pada kebun kelapa sawit pun pencurian hasil (termasuk pencurian buah yang masih muda) menyebabkan pembuahan berikutnya tidak sempurna. Pada kebun tebu pembabatan atau pembakaran tebu menyebabkan kebun tidak dapat dipanen. Selain itu, berbagai gangguan usaha perkebunan tersebut menyebabkan terganggunya kinerja para pegawai perusahaan karena merasa jiwanya terancam.

Pada lingkungan masyarakat, konflik perkebunan juga menimbulkan berbagai kerugian berikut (Fadjar, 2009): a) Hilangnya rasa aman dan hilangnya kesempatan kerja, b) Terjadinya konflik horizontal diantara anggota masyarakat sendiri, c) Munculnya free rider dan "petualang" yang mengambil keuntungan atas upaya perusahaan Perkebunan maupun masyarakat sekalipun dalam kenyataannya mereka tidak ikut berusaha, d) Masyarakat lapisan bawah yang posisinya hanya sebagai pengikut terjebak dalam tindakan kriminal sehingga mereka menjadi sasaran penangkapan aparat keamanan.

Tabel 9.

Perkembangan Gangguan Usaha Perkebunan (2012 -2015) Tahun

Jenis GUP

\begin{tabular}{ccccc} 
& Lahan & Non Lahan & Kehutanan & Jumlah \\
\hline 2012 & 539 & 185 & 15 & 739 \\
\hline 2013 & 463 & 135 & 33 & 631 \\
\hline 2014 & 576 & 233 & 25 & 834 \\
\hline 2015 & 494 & 159 & 37 & 690 \\
\hline Total & 2.072 & 712 & 110 & 2.894 \\
\hline$\%$ & $\mathbf{7 1 , 6}$ & $\mathbf{2 4 , 6}$ & $\mathbf{3 , 8}$ & $\mathbf{1 0 0 , 0}$ \\
\hline
\end{tabular}

Sumber Data: Hasil Riset PT RPN. Diolah. 
Pemicu utama timbulnya konflik penguasaan lahan antara perusahaan perkebunan dengan masyarakat sekitar yang bersumber pada reclaiming lahan adalah (Fadjar, dkk. 2002): 1) ketidak sepakatan nilai dan mekanisme pembebasan lahan adat, 2) ketidak sepakatan nilai dan mekanisme pembebasan lahan garapan dan atau pemukiman masyarakat yang menurut hak erfacht lahan tersebut merupakan lahan cadangan perkebunan, 3) adanya persepsi masyarakat bahwa mereka mempunyai hak untuk memiliki lahan yang dikuasai perusahaan perkebunan. Tumbuhnya persepsi masyarakat tersebut berkaitan dengan hal-hal berikut: a) para pekebun menggarap lahan yang diterlantarkan oleh perusahaan perkebunan, b) pekebun pernah ikut serta membuka kebun (zaman Jepang/Belanda), c) sebelum program nasionalisasi perkebunan swasta asing diterapkan di lokasi kebun tersebut telah berdiri perumahan dan terbit hak pakai, d) mengacu pada hukum agraria, pada tahun 1961 rakyat pernah diminta mendaftarkan tanah namun tidak jelas kelanjutannya, e) pada tahun 19651966 terjadi pemindahan masyarakat yang tinggal di areal kebun dengan pendekatan keamanan karena orang yang ada di lokasi tersebut dianggap anggota partai terlarang, f) tersebarnya informasi bahwa luas lahan yang dikuasai kebun melebihi luas yang tercantum dalam sertifikat HGU atau HGU nya sudah habis sehingga masyarakat sekitar menganggap berhak memiliki lahan tersebut, g) lahan yang digunakan perusahaan perkebunan sebelumnya merupakan lahan adat tanpa melalui pembebasan yang disepakati para pihak.

Berbagai pemicu konflik tersebut akan efektif menjadi penyebab konflik dengan proses yang lebih cepat manakala terdapat situasi kesenjangan ekonomi antara komunitas perusahaan perkebunan dengan masyarakat sekitar (Ivanovic dan Fadjar, 2002). Selain itu, manakala pemicu konflik yang berdasar pada reclaiming lahan tersebut tidak segera diselesaikan, maka akan muncul konflik perkebunan yang lebih luas yang didorong oleh adanya kelompok pelaku yang didasarkan pada motif kriminal (sekelompok orang yang menjarah kebun untuk dijual) serta kelompok pelaku yang digerakkan oleh pemimpin local yang kharismatik.

Berdasarkan data rekapitulasi konflik pada tahun 2001 yang terdapat di Ditjenbun (Ivanovic dan Fadjar, 2002), proporsi konflik penguasaan lahan yang terjadi antara masyarakat dengan perkebunan besar swasta lebih besar dibanding yang terjadi antara masyarakat dengan perkebunan besar negara. Dalam hal ini, objek lahan konflik pada perkebunan besar negara hanya 143 ribu hektar atau $17,4 \%$ dari total luas lahan yang dikuasai perkebunan besar negara, sedangkan pada perkebunan swasta objek lahan konflik mencapai 179 ribu hektar atau $36 \%$ dari total luas lahan yang dikuasai perkebunan besar swasta. Selain itu, konflik lahan perkebunan juga terjadi antar perusahaan perkebunan atau antara masyarakat pekebun atau perusahaan perkebunan dengan pemerintah (pemilik lahan kehutanan), akan tetapi kasuskasus tersebut jumlahnya relatif lebih kecil.

\section{Keterkaitan Antar Aspek dalam Penentuan Batasan Luas Maksimum Penggunaan Lahan untuk Usaha Perke- bunan Kelapa Sawit}

Pengelolaan perkebunan komoditas kelapa sawit pada umumnya merupakan suatu sistem yang di dalamnya terdapat kompleksitas yang tinggi. Dalam hal ini, sistem yang kompleks tersebut dibedakan ke dalam beberapa aspek yaitu aspek teknis, ekonomi, sosial, serta regulasi dan kebijakan. Keempat aspek tersebut secara simultan saling berinteraksi membangun sistem usaha perkebunan dari hulu sampai ke hilir. 


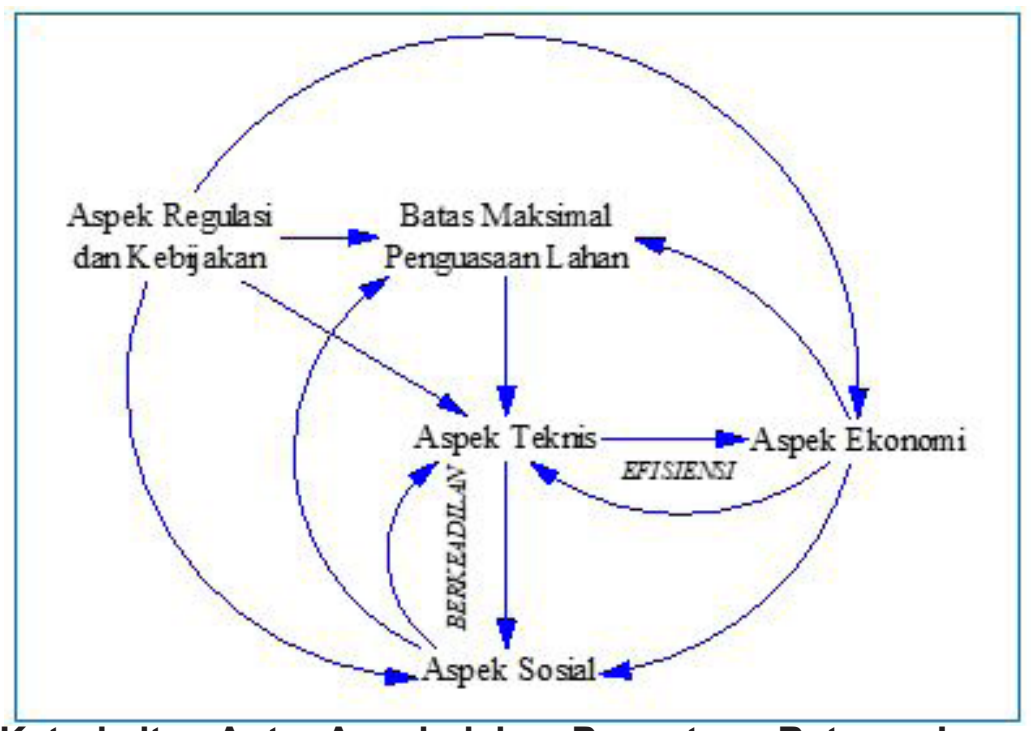

\section{Gambar 8. Keterkaitan Antar Aspek dalam Penentuan Batasan Luas Maksimum Penggunaan Lahan untuk Usaha Perkebunan}

Asas berkeadilan dan efisiensi yang menjadi salah satu asas dalam penyelenggaraan usaha perkebunan kelapa sawit dan secara empiris memiliki peran yang berhubungan dengan aspek sosial, ekonomi, teknis, maupun dalam aspek regulasi dan kebijakan. Penyelenggaraan perkebunan kelapa sawit apabila digambarkan secara umum dalam suatu struktur yang saling berkaitan dibangun oleh aspek sosial, ekonomi, teknis, serta regulasi dan kebijakan. Asas efisiensi pada prakteknya tidak berdiri sendiri, ditentukan oleh aspek teknis, aspek ekonomi dan aspek sosial. Demikian halnya dengan asas berkeadilan juga ditentukan oleh aspek sosial, ekono$\mathrm{mi}$, dan regulasi.

Asas efisiensi pada prakteknya tidak berdiri sendiri, efisiensi dalam penyelenggaraan usaha perkebunan kelapa sawit secara langsung ditentukan oleh aspek teknis dan aspek ekonomi, serta secara tidak langsung ditentukan oleh aspek sosial serta aspek regulasi dan kebijakan. Demikian halnya dengan asas berkeadilan juga ditentukan secara langsung oleh aspek sosial dan aspek teknis. Aspek sosial sebagai penentu terciptanya asas berkeadilan tidak bisa dipisahkan dari aspek teknis dan ekonomi.
Agar lebih operasional, untuk melihat bagaimana penetapan luas maksimum penggunaan lahan pada usaha perkebunan kelapa sawit oleh perusahaan perkebunan, keempat aspek tersebut secara keseluruhan dikelompokkan menjadi beberapa klaster yang diturunkan ke dalam beberapa kriteria dan indikator. Rincian kriteria pada setiap aspek adalah sebagai berikut: 1) Kriteria pada Aspek Teknis: produksi kebun Perkebunan Besar Swasta, produksi Perkebunan Rakyat, potesi lahan perkebunan dan produksi pengolahan Perkebunan Besar Swasta. 2) Kriteria pada Aspek Ekonomi: modal finansial, tenaga kerja, pendapatan perisahaan, daya serap pasar, skala ekonomis dan harga komoditas. 3) Kriteria pada Aspek Sosial: ketimpangan penguasaan lahan, konflik masyarakat dengan perusahaan dan pola pengembangan usaha. 4) Kriteria pada Aspek Regulasi dan Kebijakan: fungsi tata ruang, pembatasan penguasaan dan penggunaan lahan, persaingan usaha serta kepentingan nasional.

Secara lebih spesifik, berbagai aspek dan kriteria yang disebutkan di atas kemudian diterjemahkan ke dalam berbagai indikator ijin usaha perkebunan yang terintegrasi dengan pengolahan primer 
(sawit, tebu dan teh). Pada ijin usaha perkebunan yang terintegrasi (IUP) industri pengolahan produk perkebunan berada dalam satu kawasan perkebunan yang terintegrasi dengan aktivitas budidaya. Perbedaan tersebut membedakan kriteria dan indikator dari setiap aspek yang ijin usaha perkebunan, baik ijin usaha perkebunan terintegrasi (IUP) maupun ijin usaha perkebunan budidaya (IUP-B).

Penetapan kriteria dan indikator pembentuk kriteria tersebut dilakukan dengan menggunakan diagram sebab akibat (causal loop diagram) dimana terdapat keterkaitan antar aspek dan kriteria pembantuknya. Sebagian aspek dan kriteria yang saling terkait dalam struktur diagram sebab akibat dibangun oleh berbagai unsur yang sesuai dengan ketentuan yang terdapat Undang-Undang Perkebunan Nomor 39 Tahun 2014.

Diagram sebab akibat (causal loop diagram) digambarkan dengan menggunakan alat analisis yang disebut dengan sistem archetype, alat analisis ini digunakan dalam rangka mengenali pola tingkah laku sistem. Archetype dalam diagram sebab akibat menggambarkan garis cerita dengan tema tersendiri dan pola tingkah laku yang khusus. Keterkaitan antar unsur dari berbagai kriteria yang terdiri dari aspek teknis, aspek ekonomi, aspek sosial serta aspek regulasi dan kebijakan digambarkan dalam sebuah struktur yang di dalamnya dibangun oleh unsur-unsur perkebunan sebagaimana disebutkan dalam Undang-undang Perkebunan Nomor 39 Tahun 2014.

Hubungan sebab akibat dalam sistem archetype digambarkan dengan menggunakan anak panah yang ujungnya bertanda positif $(+)$ atau negatif $(-)$. Anak panah bertanda positif mempunyai arti bahwa sebab akan menambah akibat atau sebab akan mempengaruhi akibat dalam arah perubahan yang sama. Arah perubahan yang sama berarti bahwa jika sebab meningkat (atau menurun), pengaruhnya terhadap akibat akan menyebabkan akibat yang meningkat (atau menurun). Sedangkan anak panah bertanda negatif mempunyai arti bahwa sebab akan mengurangi akibat atau sebab mempengaruhi akibat dalam arah perubahan yang berlawanan. Arah perubahan yang berawanan berarti bahwa jika sebab meningkat (atau menurun), pengaruhnya terhadap akibat akan sebaliknya yaitu menyebabkan akibat yang menurun (atau meningkat).

Lingkar sebab-akibat positif akan menghasilkan suatu perilaku pertumbuhan (growth) atau penurunan (peluruhan). Lingkar sebab akibat positif (Reinforcing) yang ditulis dengan notasi "R". Sedangkan lingkar sebab-akibat negatif akan menghasilkan suatu perilaku pencapaian tujuan (goal seeking). Lingkar sebab akibat negatif merupakan suatu proses penyeimbangan (Balancing process) yang ditulis dengan notasi "B".

Asas berkeadilan dan asas efisiensi dalam penentuan batas maksimal luas lahan adalah dua konsep yang pada praktek usaha perkebunan saling berinteraksi satu sama lain antara kriteria dan indikator dari aspek teknis, aspek ekonomi, aspek sosial dan aspek kebijakan. Indikator dan kriteria yang diperoleh dari hasil diskusi kelompok terfokus para pakar di bidang perkebunan kemudian digabungkan dalam suatu struktur diagram sebab akibat (Causal Loop Diagram/CLD) menggunakan pendekatan sistem archetype (lihat Gambar 11 dan Gambar 12). Causal Loop Diagram Penentuan Batas Luas Maksimum Penggunaan Lahan pada Usaha Perkebunan). Adapun saling keterkaitan antar aspek dan kriteria di dalam masing-masing aspek maupun keterkaitan antar kriteria dengan aspek lainnya dapat dilihat pada Gambar 8.

Perusahan Besar Swasta (PBS) baik yang terintegrasi (budidaya dan pengolahan) maupun hanya budidaya saja akan mencapai skala yang ekonomis apabila biaya produksi dapat ditekan pada 
tingkat yang rendah untuk setiap satuan produk yang dihasilkan. Perusahaan dengan skala ekonomis yang baik akan menghasilkan tingkat efisiensi yang tinggi. Perusahaan perkebunan yang efisien akan menerima pendapatan yang tinggi karena biaya yang dikeluarkan untuk satuan produksi berada pada titik optimal. Hal ini disebabkan oleh modal finansial yang digunakan perusahaan untuk investasi teknologi dan pemenuhan biaya produksi mampu meningkatkan produktivitas perusahaan, terutama pada usaha budidaya.

Bagi perusahaan swasta skala besar, tingginya investasi teknologi dan besarnya biaya sarana produksi dapat dijangkau dengan mudah disebabkan oleh besarnya modal finansial sebagai akibat dari proses usaha yang efisien baik dari usaha budidaya perkebunan maupun pengolahan. Siklus ini terus berputar membentuk suatu umpan balik (feedback) positif (loop R1 pada Gambar 9) yang menimbulkan pertumbuhan dalam usaha perusahaan besar swasta.

Pertumbuhan usaha yang tinggi pada perusahaan besar swasta (PBS) tidak dapat diimbangi oleh usaha perkebunan rakyat $(P R)$ yang proses pertumbuhannya relatif lebih lambat dibandingkan dengan PBS. Hal ini diperlihatkan dengan penguasaan lahan usaha budidaya perkebunan kelapa sawit miliki Perusahaan Besar Swasta (PBS) yang terus bertambah secara progresif pada satu dasawasa terakhir. Kondisi ini menimbulkan ketimpangan yang semakin melebar antara perkebunan besar sawasta (PBS) dengan Perkebunan Rakyat (PR). Persaingan antara PBS dan PR dilihat dari besarnya kesenjangan penguasaan lahan menimbulkan persaingan usaha yang tidak sehat dan mengikis asas berkeadilan yang seharusnya menjadi acuan dalam penyelenggaraan usaha perkebunan (UU Nomor 39 tahun 2014 tentang Perkebunan). Munculnya berbagai konflik di sekitar lingkungan perusahaan besar swasta (khususnya kelapa sawit) disebabkan oleh persaingan usaha yang tidak sehat yang berawal dari tingginya tingkat ketimpangan antara perusahaan besar swasta dengan perkebunan rakyat di sekitarnya. Walau kecil, namun dampak dari konflik di lingkungan perkebunan cukup mengganggu jalannya operasional perkebunan, dan apabila dibiarkan dalam beberapa kasus dapat berkembang menjadi skala yang besar (loop R2 pada Gambar 11).

Pemerintah sebagai regulator sebenarnya telah berupaya untuk mengurangi dampak dan mecegah terjadinya ketimpangan yang berlebihan antara perkebunan besar swasta dengan perkebunan rakyat melalui regulasi kewajiban menjalin kemitraan dan kewajiban memfasilitasi pembangunan kebun masyarakat sekitar yang harus dilakukan oleh setiap perusahaan besar terhadap perkebunan rakyat. Hal ini bertujuan untuk meredam konflik antara masyarakat lokal (pekebunan rakyat/PR) dengan perusahaan besar swasta (loop R3 pada Gambar 11). Namun demikian implementasi dari regulasi tersebut kurang berjalan dengan baik disebabkan oleh kompleksitas yang tinggi dalam penyelenggaraan perkebunan termasuk pengawasan dan pengelolaan di dalamnya.

Dilihat dari kacamata sistem archetype, asas berkeadilan (loop R2 dan R3) dan asas efisiensi (loop R1) pada dasarnya dapat berjalan bersamaan dalam praktek penyelenggaraan usaha perkebunan. Semakin efisiensi suatu persahaan besar swasta maka pendapatannya akan terus bertambah. Artinya dari sisi kewajiban terhadap lingkungan masyarakat (termasuk fasilitasi pembangunan kebun masyarakat sekitar dan kemitraan) akan bertambah banyak, sehingga dapat mengurangi konflik dan ketimpangan antara Perkebunan Besar Swasta (PBS) dengan para pekebun atau perkebunan rakyat (PR). 


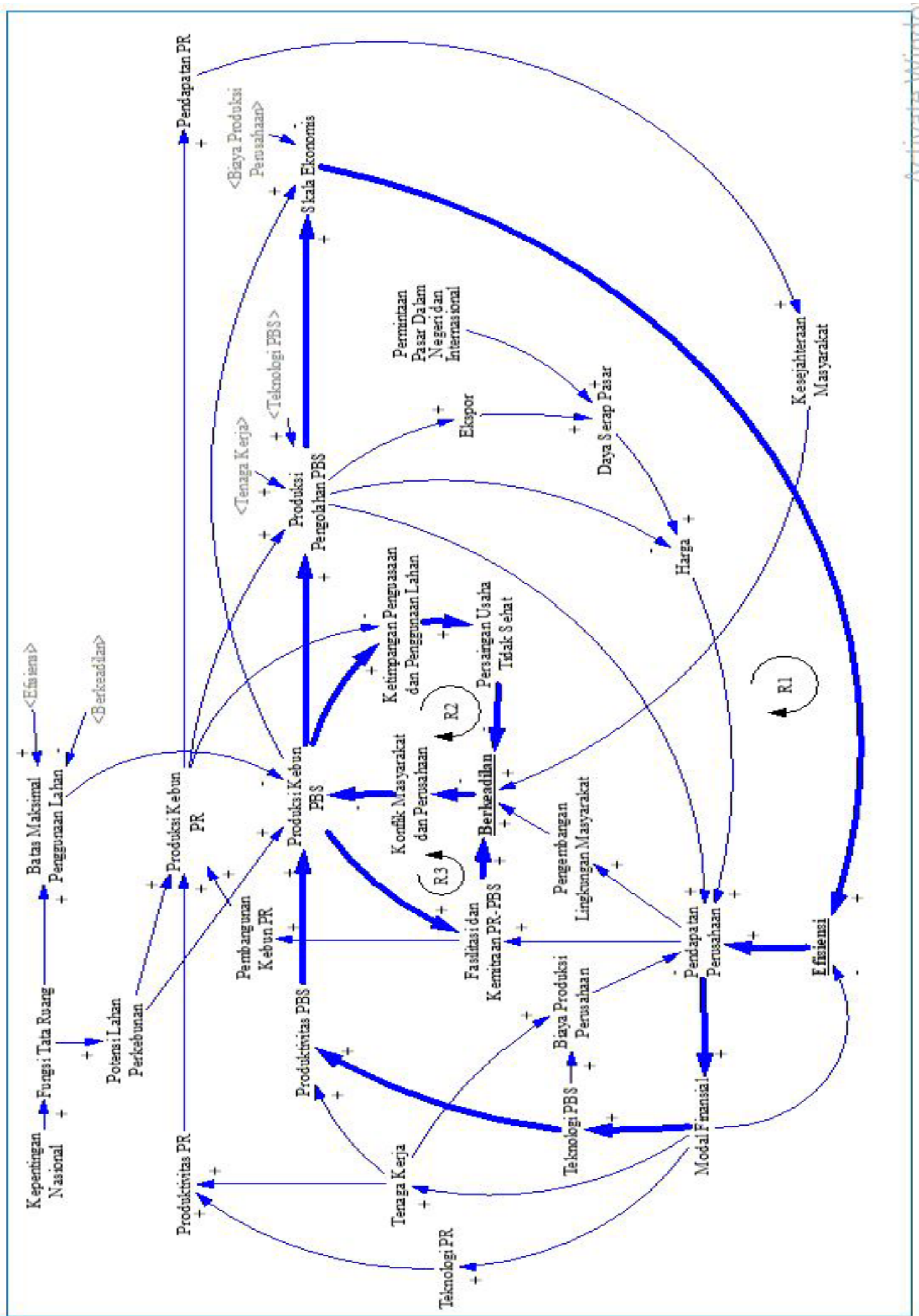

Gambar 9. Causal Loop Diagram Penentuan Batas Luas Maksimum Penggunaan Lahan pada Usaha Perkebunan Kelapa Sawit Terintegrasi 
Secara konseptual terjadi transfer nilai dari PBS kepada PR melalui kewajiban memfasilitasi pembangunan kebun masyarakat sekitar dan kemitraan antara PBS dengan PR. Peningkatan kapasitas PR dapat difasilitasi oleh PBS dalam hal perluasan kebun PR maupun peningkatan produktivitas agar produksi PR dapat meningkat dan mencapai efisiensi yang layak secara ekonomi.

Pembatasan luas maksimum penggunaan lahan usaha perkebunan dalam hal ini bertujuan untuk mengurangi ketimpangan yang mungkin terjadi antara PBS dengan PR agar tidak terlalu lebar. Pemerataan kesempatan berusaha di sektor perkebunan perlu dikembangkan ke arah peningkatan daya saing produk perkebunan. Penetapan batas maksimum luas penggunaan lahan usaha perkebunan bagi perkebunan besar swasta merupakan salah satu instrumen regulasi yang berdasarkan kepada asas berkeadilan. Walau demikian, diharapkan pertimbangan asas berkeadilan tersebut tetap memperhatikan asas efisiensi guna menghindari terjadinya involusi yang merupakan disinsentif bagi usaha sektor perkebunan.

Merujuk kepada causal loop diagram di atas, dapat diidentifikasi bahwa penentuan batas luas maksimum penggunaan lahan pada usaha perkebunan harus memperhatikan asas berkeadilan, asas efisiensi serta regulasi dan kebijakan. Penerapan asas berkeadilan dalam penyelenggaraan usaha perkebunan lebih kompleks dibandingkan dengan penerapan asas efisiensi. Asas berkeadilan dibangun oleh aspek sosial, aspek teknis dan aspek ekonomi, sedangkan asas efisiensi lebih banyak ditentukan oleh aspek ekonomi. Asas berkeadilan dalam usaha perkebunan yang menjadi penentu batas luas maksimal penguasaan lahan dibentuk oleh aspek sosial, aspek teknis, aspek ekonomi serta aspek regulasi dan kebijakan. Aspek sosial yang membentuk asas berkeadilan di antaranya: fasilitasi dan kemitraan antara perkebunan rakyat $(P R)$ dan perkebunan besar swasta (PBS). Aspek regulasi dan kebijakan yang membentuk asas berkeadilan adalah persaingan usaha tidak sehat yang bersumber dari ketimpangan penguasaan dan penggunaan lahan antara PR dan PBS. Penguasaan dan penggunaan lahan merupakan salah satu indikator yang digunakan sebagai penentu penggunaan sarana produksi dalam aspek teknis usaha perkebunan. Selanjutnya aspek ekonomi yang membentuk asas berkeadilan adalah pendapatan PR yang ditentukan oleh produksi kebun PR.

Berbeda dengan asas berkeadilan, asas efisiensi dalam usaha perkebunan kelapa sawit yang menjadi penentu batas maksimal kepemilikan dan penguasaan lahan lebih dominan dibentuk oleh aspek ekonomi seperti modal finansial perusahaan dan skala ekonomis. Komponen manajemen perusahaan perkebunan

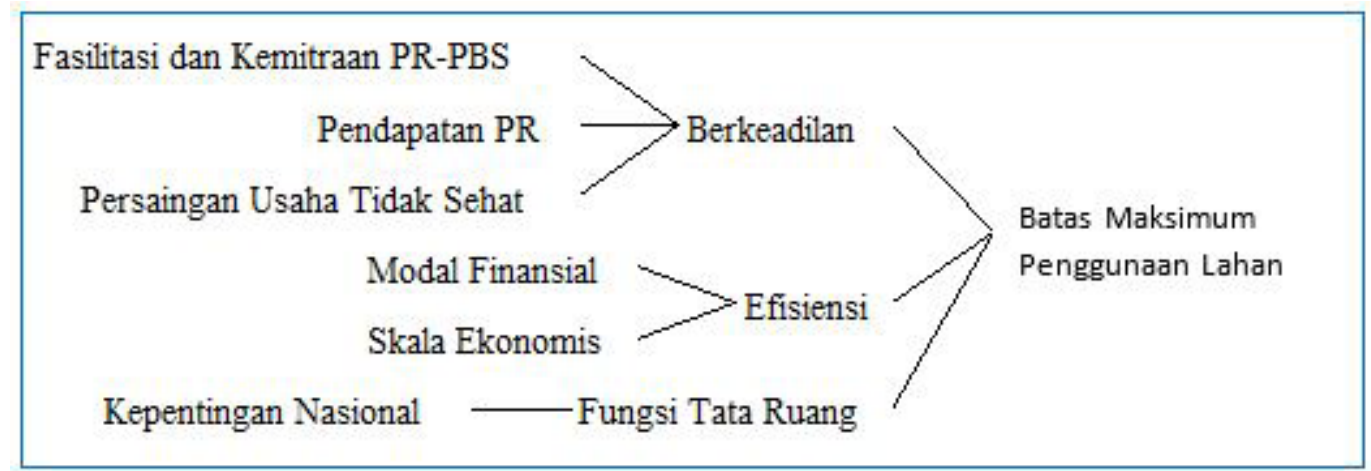

Gambar 10. Causal Tree Diagram Penentuan Batas Maksimum Penggunaan Lahan untuk Usaha Perkebunan Kelapa Sawit 
memegang peranan penting dalam menjalankan asas efisiensi ini. Pengelolaan aspek teknis perkebunan yang baik akan meningkatkan skala ekonomis dan efisiensi perusahaan perkebunan, baik perusahaan yang terintegrasi budidaya dan pengolahan maupun hanya budidaya saja.

\section{Rekomendasi Kebijakan}

Pertama, penetapan peraturan pembatasan luas maksimum penggunaan lahan untuk Usaha Perkebunan Kelapa Sawit diterapkan pada 1 (satu) Perusahaan atau Kelompok (Group) Perusahaan Perkebunan untuk jenis komoditas/ tanaman perkebunan kelapa sawit perlu diusahakan.

Kedua, Dalam penerapan peraturan dimaksud pada point 1 terdapat beberapa "pengecualian", yaitu pada badan usaha yang berbadan hukum berikut: a) Badan usaha perkebunan yang dimiliki para petani (Koperasi, Badan Usaha Milik Petani). b) Badan usaha perkebunan yang dimiliki pemerintah: Badan Usaha Milik Negara/BUMN dan Badan Usaha Milik Daerah/BUMD. c)Perusahaan Perkebunan Swasta dengan status perseroan terbuka (go public) yang sebagian sahamnya dimiliki oleh masyarakat tetapi tidak ada pemilik saham (investor) yang penguasaan sahamnya setara dan/atau lebih besar dengan ketentuan "batasan luas maksimum penggunaan lahan untuk usaha perkebunan".

Ketiga, Dalam penerapan peraturan tersebut ditetapkan "ketentuan peralihan" sebagai berikut: "Peraturan luas maksimum penggunaan lahan untuk Usaha Perkebunan kelapa sawit diterapkan pada satu perusahaan setelah masa berlaku Hak Guna Usaha perusahaan tersebut berakhir". Ketentuan peralihan ini bertujuan untuk: a) menghindari terjadinya kekosongan hukum; b) menjamin kepastian hukum; c) memberikan perlindungan hukum bagi pihak yang terkena dampak perubahan ketentuan Peraturan Perundang- -undangan; dan d) mengatur hal-hal yang bersifat transisional atau bersifat sementara.

\section{Implikasi Kebijakan}

Agar implementasi peraturan Luas

Maksimum Penggunaan Lahan untuk Usaha Perkebunan kelapa sawit ini berjalan efektif, perlu dilakukan: Satu, Harmonisasi Peraturan, khususnya dengan: 1) UU Nomor 5 Tahun 1999 tentang UU Larangan Praktek Monopoli dan Persaingan Usaha Tidak Sehat (Pasal 27), 2) Peraturan Menteri ATR/Kepala BPN Nomor 5 Tahun 2015 tentang Izin Lokasi untuk Usaha Perkebunan (Pasal 4), 3) PP RI No 40 Tahun 1996 tentang HGU, HGB \& HAK PAKAI ATAS TANAH. Dua, Pengawalan oleh Tim khusus yang mewakili instansi terkait lintas K/L (Kementerian/Lembaga), terutama Kementerian Pertanian, Kementerian Agraria dan Tata Ruang/Badan Pertanahan Nasional, Kementerian Lingkungan Hidup dan Kehutanan, Badan Koordinasi Penanaman Modal (BKPM), dan Komisi Pengawas Persaingan Usaha (KPPU).

Kebijakan pembatasan Luas Maksimum Penggunaan Lahan untuk Usaha Perkebunan kelapa sawit sejalan dengan Kebijakan Pembangunan Ekonomi Berkeadilan melalui Agrarian Reform yang menjadi fokus pemerintah. Kebijakan pembatasan Luas Maksimum Penggunaan Lahan ini akan memberi jalan yang lebih besar bagi para pekebun untuk memperoleh akses penguasaan lahan. Dalam hal ini, para pekebun memperoleh akses untuk menguasai lahan dengan "luas ideal" agar mereka mendapatkan penghasilan yang cukup guna membiayai pengelolaan kebun secara intensif; peremajaan tepat waktu; dan pengeluaran untuk mensejahterakan anggota keluarganya. Pengawasan distribusi penguasaan lahan di antara pekebun perlu dilakukan agar tidak terjadi ketimpangan pada aras mikro (komunitas pekebun). 
Selain itu, agar akses penguasaan lahan yang diperoleh para pekebun diikuti dengan pengelolaan lahan secara produktif maka kebijakan ini perlu dilengkapi dengan program optimalisasi pemanfaatan lahan melalui: a) Program Pengembangan dan Peningkatan Produktivitas Perkebunan Rakyat melalui Pembangunan Kebun, Intensifikasi dan Peremajaan yang didukung penyediaan kredit dengan bunga rendah serta skema pengembalian kredit yang sesuai karakteristik masingmasing tanaman. b) Program Penguatan SDM dan Kelembagan Pekebun untuk meningkatkan kemampuan dan kemandirian mereka dalam menguasai teknologi, input produksi, dan pasar sehingga mereka dapat melaksanakan program Pengembangan dan Peningkatan Produktivitas Perkebunan Rakyat melalui kegiatan pembangunan kebun, intensifikasi kebun dan peremajaan kebun. c) Mengutamakan kelestarian lingkungan.

Adanya pembatasan luas maksimum penggunaan lahan bagi perusahaan perkebunan kelapa sawit perlu dibarengi dengan semakin kondusifnya iklim usaha di industri hilir berbasis bahan baku hasil perkebunan bagi perusahaan besar. Dengan demikian, keterbatasan peluang berusaha di hulu akibat pembatasan luas maksimum penggunaan lahan tersebut dapat tergantikan dengan semakin terbuka dan menariknya peluang usaha di hilir. Lebih lanjut, semakin berkembangnya industri hilir berbasis bahan baku hasil perkebunan oleh perusahaan besar perlu didorong untuk menjadi lokomotif bagi berkembangnya industri hulu (kebun) yang dikelola pekebun; UKM; Koperasi.

\section{Kesimpulan}

Struktur penguasaan lahan pada usaha perkebunan, berbeda antar komoditas perkebunan. Pada usaha kelapa sawit, penguasaan lahan didominasi oleh perkebunan besar yaitu 59,7\%. Pada usaha kelapa sawit, penguasaan lahan oleh perusahaan swasta jauh lebih dominan dari pada perusahaan negara, yaitu masing-masing $53,1 \%$ dan $6,6 \%$. Sejalan dengan struktur penguasaan lahan tersebut, ketimpangan penguasaan lahan tertinggi terjadi pada usaha kelapa sawit yang berada pada kategori "ketimpangan sedang". Dalam hal ini 40\% pelaku usaha kebun kelapa sawit yang seluruhnya merupakan pekebun hanya menguasai $15,7 \%$ total lahan kelapa sawit. Dipihak lain, 25 group perusahaan swasta menguasai $43 \%$ total lahan kelapa sawit (4,8 juta hektar). Ketimpangan penguasaan lahan usaha kelapa sawit akan semakin tinggi manakala pengambilalihan lahan perusahaan perkebunan PMDN oleh PMA berlangsung intensif. Sementara itu, pada 10 komoditas unggulan strategis nasional perkebunan lainnya struktur penguasaan lahan masih berada pada kategori "ketimpangan rendah".

Bila kondisi ketimpangan terus tumbuh bersamaan dengan masih adanya pengangguran dan kemiskinan di wilayahwilayah usaha perkebunan, maka kondisi ini akan mendorong terjadinya konflik sosial. Kondisi ini bila dibiarkan sangat potensial menimbulkan iklim usaha yang tidak kondusif dan kemudian akan mengganggu berlangsungnya usaha perkebunan secara keseluruhan.

Kebijakan yang dilakukan dapat memperhatikan kelestarian lingkungan sehingga usaha perkebunan yang dikelola oleh seluruh pelaku usaha perkebunan akan berjalan secara berkelanjutan karena dapat meredam konflik sosial yang bersumber dari ketidakadilan penguasaan sumber daya lahan.

Sub-sektor perkebunan masih dituntut untuk terus berperan dalam penyediaan lapangan berusaha/bekerja dan dalam mengatasi kemiskinan". Hal ini diperlukan mengingat angkatan kerja di Indonesia terus meningkat sejalan pertumbuhan penduduk $(1,4 \%$ per tahun periode 2000 - 2014), pengangguran masih terus 
terjadi karena pertumbuhan angkatan kerja lebih kecil dari pada peluang bekerja/ berusaha (Tahun 2001 sebanyak 8 juta dan tahun 2013 sebanyak 7,3 juta), dan kemiskinan juga masih terjadi di seluruh provinsi (tahun 2015 sebanyak 11,7\% penduduk Indonesia masih miskin). Penduduk miskin tersebut terjadi baik pada kelompok penduduk yang tidak bekerja sebesar $26 \%$ ataupun yang bekerja di sektor pertanian sebesar $36 \%$ (termasuk yang bekerja di sub sektor perkebunan) maupun yang bekerja di sektor non pertanian sebesar $38 \%$.

UU Perkebunan Nomor 39 Tahun 2014 (pasal 14 ayat 1) mengamanatkan bahwa pemerintah pusat perlu menetapkan batasan luas maksimum dan luas minimum penggunaan lahan untuk Usaha Perkebunan. Kemudian pada pasal 14 ayat 3 UU Perkebunan disebutkan bahwa ketentuan lebih lanjut mengenai penetapan batasan luas diatur dalam Peraturan Pemerintah. Sementara itu, sampai saat ini amanat UU Perkebunan tersebut hanya terdapat dalam Peraturan Menteri Pertanian RI Nomor 98/Permentan/OT.140/9/2013 tentang Pedoman Perizinan Usaha Perkebunan.

Selain itu, berdasarkan hasil analisis peraturan perundang-undangan menunjukkan bahwa penetapan batas luas maksimum penggunaan lahan untuk Usaha Perkebunan perlu dilakukan karena memiliki landasan filosofis, landasan sosiologis serta terdapat sejumlah peraturanperundang-undangan lain yang sejalan.

\section{Landasan Filosofis}

Pasal 33 UUD 1945 melarang adanya penguasaan sumber daya alam ditangan Perorangan atau Pihak-pihak tertentu. Dengan kata lain monopoli, oligopoli maupun praktek kartel dalam bidang pengelolaan sumber daya alam dianggap bertentangan dengan prinsip Pasal 33 UUD 1945.

\section{Landasan Sosiologis}

Pertama, asas-asas yang berkaitan dengan "keharusan" pengaturan luas maksimum penggunaan lahan pada Usaha Perkebunan untuk mengharmoniskan kepentingan beragam pelaku yang kemampuannya berbeda, yaitu: a) Asas Landreform dalam UUPA: pasal 7 (untuk tidak merugikan kepentingan umum maka pemilikan dan penguasaan tanah yang melampaui batas tidak diperkenankan), pasal 17 (ayat 1: luas maksimum/ minimum hak atas tanah satu keluarga atau badan hukum harus diatur, ayat 2: diatur dengan peraturan perundangan, ayat 3 dan 4: pengaturan peralihan (mekanisme dan tahapan pelaksanaan peralihan). b) Asas Tata Guna Tanah dalam UUPA: pasal 13 (ayat 2: pemerintah mencegah adanya usaha-usaha dalam lapangan agraria dari organisasi-organisasi dan perseorangan yang bersifat monopoli swasta). c) Asas Kebermanfaatan dan Berkeadilan dalam UU Perkebunan: Pasal 14 (ayat 1: Pemerintah Pusat menetapkan batasan luas maksimum dan minimum penggunaan lahan untuk Usaha Perkebunan, ayat 2: dasar pertimbangan dalam penetapan batasan luas maksimum, dan ayat 3: perlunya peraturan pemerintah untuk penetapan batasan luas)

Kedua, asas-asas yang berkaitan dengan "kewenangan" membuat pengaturan luas maksimum penggunaan lahan untuk Usaha Perkebunan diatur sebagai Hak Menguasai dari Negara/HMN dalam UUPA: pasal 2 ayat 2 (sebagaimana termaktub dalam pasal 2 ayat 1 UUPA).

Ketiga, peraturan dan perundangundangan yang sejalan dengan pengaturan luas maksimum penggunaan lahan untuk Usaha Perkebunan yaitu: 1) UU RI Nomor 19 Tahun 2013: Perlindungan dan Pemberdayaan Petani, dalam : pasal 7 (Ayat 3: strategi pemberdayaan petani dilakukan melalui konsolidasi dan jaminan luasan lahan pertanian, pasal 60 (pemberian lahan pertanian terutama kepada petani setempat yang: a. tidak memiliki lahan, b. memiliki lahan pertanian kurang dari 2 (dua) hektar. 2) UU RI Nomor 25 Tahun 
2007: Penanaman Modal, dalam pasal 4 Ayat 2 dan pasal 13 (perlunya prioritas kesempatan dan perlindungan UMKM serta pencadangan untuk UMKM). 3) UU Nomor 5 Tahun 1999: UU Larangan Praktek Monopoli dan Persaingan Usaha Tidak Sehat, dalam Pasal 27: 1 (satu) pelaku usaha/kelompok pelaku usaha menguasai lebih dari $50 \%, 2$ - 3 pelaku usaha/kelompok pelaku usaha menguasai lebih dari 75\%. 4) PP RI Nomor 40 Tahun 1996 tentang HGU, HGB dan Hak Pakai Atas Tanah dalam pasal 5 ayat 2: Luas maksimum HGU untuk Badan Hukum ditetapkan oleh Menteri dengan pertimbangan satuan usaha paling berdayaguna. 5) Peraturan Menteri Agraria dan Tata Ruang/Kepala Badan Pertanahan Nasional Nomor 5 Tahun 2015 tentang Izin Lokasi untuk usaha perkebunan yang diusahakan dalam bentuk perkebunan besar dengan diberikan HGU (Pasal 4).

Untuk point 3) sampai dengan 5), meskipun secara yuridis sejalan dengan pengaturan batasan luas maksimum penggunaan lahan untuk Usaha Perkebunan tetapi masih diperlukan harmonisasi hukum.

\section{Landasan Yuridis}

Pertimbangan hukum perlunya pengaturan pembatasan luas lahan perkebunan ini adalah untuk mengatasi permasalahan hukum dengan mempertimbangkan aturan yang telah ada. Oleh karenanya peraturan yang masih ada perlu dirubah atau dicabut guna menjamin kepastian hukum dan rasa keadilan masyarakat. Dalam hal ini adalah peraturan pembatasan luas maksimal penggunaan lahan untuk usaha perkebunan yang terdapat dalam Permentan RI No 98/Permentan/OT.140/9/ 2013 tentang Pedoman Perizinan Usaha Perkebunan. Saat ini, posisi peraturan tersebut kurang kuat karena secara hirarki tidak dudukung oleh Peraturan Pemerintah.

Namun demikian, Peraturan Perundang-undangan yang masih ada, selama belum disahkannya Rancangan Peraturan Pemerintah (RPP) ini, tetap diakui keberadaannya dan mempunyai kekuatan hukum mengikat sepanjang diperintahkan oleh Peraturan Perundang-undangan yang lebih tinggi atau dibentuk berdasarkan kewenangan.

Hasil analisis fakta empiris tentang kondisi struktur dan ketimpangan dalam penguasaan lahan serta kebutuhan lapangan berusaha dan kondisi kemiskinan di pedesaan, hasil ANP tentang persepsi para pakar terkait prioritas pembatasan luas lahan maksimum untuk usaha perkebunan, serta hasil analisis peraturan perundang-undangan menunjukkan perlunya peraturan tentang penetapan batasan luas maksimum penggunaan lahan untuk usaha perkebunan.

Merujuk kepada analisa sistem (System Dynamics) dapat diidentifikasi bahwa penentuan batas luas maksimum penggunaan lahan pada usaha perkebunan kelapa sawit harus dilakukan dengan memperhatikan asas berkeadilan, asas efisiensi serta regulasi dan kebijakan serta mengutamakan kelestarian lingkungan. Penerapan asas berkeadilan dalam penyelenggaraan usaha perkebunan lebih kompleks dibandingkan dengan penerapan asas efisiensi. Asas berkeadilan dibangun oleh aspek sosial, aspek teknis dan aspek ekonomi, sedangkan asas efisiensi lebih banyak ditentukan oleh aspek ekonomi. Asas berkeadilan dalam usaha perkebunan yang menjadi penentu batas luas maksimal penguasaan lahan dibentuk oleh aspek sosial, aspek teknis, aspek ekonomi serta aspek regulasi dan kebijakan. Aspek sosial yang membentuk asas berkeadilan di antaranya: fasilitasi dan kemitraan antara perkebunan rakyat (PR) dan perkebunan besar swasta (PBS). Aspek regulasi dan kebijakan yang membentuk asas berkeadilan adalah persaingan usaha tidak sehat yang bersumber dari ketimpangan penguasaan dan penggunaan lahan antara PR dan PBS. Penguasaan dan penggunaan lahan merupakan salah satu indikator yang digunakan sebagai penentu 
penggunaan sarana produksi dalam aspek teknis usaha perkebunan. Selanjutnya aspek ekonomi yang membentuk asas berkeadilan adalah pendapatan PR yang ditentukan oleh produksi kebun PR

Berbeda dengan asas berkeadilan, asas efisiensi dalam usaha perkebunan kelapa sawit yang menjadi penentu batas maksimal kepemilikan dan penguasaan lahan lebih dominan dibentuk oleh aspek ekonomi seperti modal finansial perusahaan dan skala ekonomis. Komponen manajemen perusahaan perkebunan memegang peranan penting dalam menjalankan asas efisiensi ini. Pengelolaan aspek teknis perkebunan yang baik akan meningkatkan skala ekonomis dan efisiensi perusahaan perkebunan, baik perusahaan yang terintegrasi budidaya dan pengolahan maupun hanya budidaya saja. Selain itu, menjaga kelestarian lingkungan sehinggga usaha perkebunan yang dikelola oleh seluruh pelaku usaha perkebunan akan berjalan secara berkelanjutan karena dapat meredam konflik sosial yang bersumber dari ketidakadilan penguasaan sumber daya lahan.

\section{Daftar Pustaka}

Biro Pusat Statistik. 2017. https://www.bps. go.id/index.php

Capricorn Indonesia Consult, 2000. Powdered Coffee Industry and Market in Indonesia. Indocommercial No. 246:322.

Commercial Global Data Research, 2016. Studi tentang Pasar dan Prospek Industri Minyak Sawit dan Turunannya di Indonesia. http://commercialglobaldataresearch.blogspot.co.id/2016/01/ penawaran-buku-studi-tentang-kondisi. html

Direktorat Jenderal Perkebunan. 2016. Tinjauan Besaran Penanaman Modal Asing Pada Usaha Perkebunan. Direktorat Jenderal Perkebunan
Direktorat Jenderal Perkebunan. 2016. Statistik Perkebunan Indonesia 2015 - 2017: Kelapa Sawit. Direktorat Jenderal Perkebunan.

Fadjar, U., Herman, dan Ivanovic Agusta. 2002. Identifikasi Konflik antara Perkebunan Besar dengan Masyarakat Sekitar. Lembaga Riset Perkebunan Indonesia.

Fadjar, Undang. 2007. Identifikasi Konflik antara Perkebunan Besar dengan Masyarakat Sekitar dan Potensi Pengembangan Modal Sosial untuk Mengatasinya. Tinjauan Komoditas Perkebunan. Vol 7 No 1 Juli 2007. Lembaga Riset Perkebunan Indonesia.

Fadjar, Undang. 2009. Penguasaan Lahan dan Implikasinya terhadap Diferensiasi Struktur Sosial dan Kesejahteraan Petani. Studi Kasus pada Dua Komunitas Petani Kelapa Sawit di Provinsi Riau. Jurnal Penelitian Kelapa Sawit. Volume 17, Nomor 3, Desember 2009.

Fadjar, Undang. 2009. Transformasi Struktur Agraria dan Diferensiasi Sosial pada Komunitas Petani. Studi Kasus Pada Empat Komunitas Petani Kakao di Propinsi Sulawesi Tengah dan Nangroe Aceh Darussalam. Disertasi. IPB.

Haryono, M. N. 2011. Sejarah Perkembangan Tanaman Kelapa Sawit di Indonesia. http://tehnikbudidayakelapasawit.blogspot.co.id/2011/09/ sejarah-perkembangan-tanamankelapa.html

Hasyim, Wan. 1988. Peasant under Peripheral Capitalism. Penerbit Universiti Kebangsaan Malaysia.

Herman, dan Fadjar. 2000. Kajian terhadap Kinerja Penerapan Lima Pola Pengembangan Perkebunan. Lembaga Riset Perkebunan Indonesia. Bogor.

Ivanovic dan Fadjar. 2002. Konflik Perkebunan Mutakhir dan Manajemen Social 
di Indonesia. Institut Pertanian Bogor. Bogor.

Kansil, CTS. 2002. Pengantar IImu Hukum dan Tata Hukum Indonesia. Balai Pustaka. Jakarta.

Kementerian Perindustrian. 2017. Pemerintah Siapkan Skema Integrasi Industri Hulu-Hilir. Siaran Pers. http://www. kemenperin.go.id/artikel/17329/ Pemerintah-Siapkan-Skema-IntegrasiIndustri-Hulu-Hilir

Lay, A. dan P. M. Pasang. 2012. Stategi, dan Implementasi Pengembangan Produuk Kelapa Masa Depan. Prosfektif. Prosfektif, Vol 11. No. 1: 1-22.

Margrit, A. 2016. Pasokan Terbatas, Utilitas Pabrik Olahan Kelapa Menyusut. 05 September 2016. http://industri.bisnis.com/read/20160905/99/581181/ pasokan-terbatas-utilitas-pabrikolahan-kelapa-menyusut

Mubyarto. Dkk. 1992. Tanah dan Tenaga Kerja Perkebunan. Aditya Media. Jogyakarta

Muchsin. 2005. Ikhtisar Ilmu Hukum, Badan Penerbit Iblam. Jakarta.

Muljadi, Kartini dan Gunawan Widjaja. 2008. Seri Hukum Harta Kekayaan. Hak-Hak Atas Tanah. Kencana. Jakarta.

Nasution, Lutfi. 2000. Pemberdayaan Peran Badan Pertanahan Nasional Dalam Mengelola Sengketa Agraria. Prosiding Pola Penguasaan Lahan dan Pola Usaha Serta Pemberdayaan BPN dan Pemda dalam Rangka Partisipasi Rakyat di sektor Perkebunan. Pusat Kajian Agraria - LP IPB. Bogor

Pakpahan, A. 2000. "Peranan HGU dalam Pengembangan Perkebunan Besar", dalam E. Soetarto, et.al., Prosiding Lokakarya Pola Penguasaan Lahan dan Pola Usaha serta Pemberdayaan BPN dan Pemda dalam Rangka Partisipasi
Rakyat di Sektor Perkebunan.

Pakpahan. A. 2016. Perkebunan Inti Rakyat (PIR) Generasi ke II: Transformasi dari Ketergantungan ke Kemandirian Ekonomi dalam Teropong Perkebunan Pemerdekaan Indonesia. Media Perkebunan

Pakpahan. A. 2016. Abad ke 21: Apa Kebijakan Lahan untuk Perkebunan? dalam Teropong Perkebunan Pemerdekaan Indonesia. Media Perkebunan

Rahardjo, Satjipto. 2000. IImu Hukum, PT. Citra Aditya Bakti. Bandung. 2000.

Russel, James W. 1989. Modes of Production in World History. Routledge. London and New York

Sajogyo. 2002. Struktur Agraria, Proses Lokal, dan Pola Kekuasaan dalam E. Suhendar dkk. (penyunting) Menuju Keadilan Agraria. AKATIGA. Bandung

Setiawan. B. 1997. Konsep Pembaharuan Agraria: Sebuah Tinjauan Umum dalam Dianto Bachriadi, dkk. (editor) Reforma Agraria: Perubahan Politik, Sengketa, dan agenda Pembaharuan Agraria.

Shanin, Teodor. 1990. Defining Peasant. Essays Conserning Rural Societies, Expolary Economies, and Learning from them in the Contemporary World. Basil Blackwell. Cambridge.

Sihombing, BF. Evolusi Kebijakan Pertanahan Dalam Hukum Tanah Indonesia, PT. Toko Gunung Agung Tbk. Jakarta www. property.net, diakses pada tanggal 20 November 2008.

Soimin, Sudharyo. 2001. Status Hak dan Pembebasan Tanah. Edisi Ketiga. Sinar Grafika, Jakarta.

Sumardjono, Maria. 2008. Tanah dalam Perspektif Hak Ekonomi, Sosial dan Budaya. Penerbit Buku Kompas. Jakarta.

Supriadi. 2008. Hukum Agraria. Sinar 
Grafika. Jakarta. 2008.

Suprihatini, R. 2015. Analisis Supply Chain Teh Indonesia. Jurnal Penelitian Teh dan Kina, (18)2: 107-118.

Susanto, P. 2014. Kebijakan Pemerintah dalam Mendorong Industri Kopi, Kakao, dan Teh di Indonesia. www.kadinindonesia.or.id/.../ RTD\%20Kakao.../ Bahan\%20Presentasi\%20Dirjen\%20I

Suwismo, A. 2016. Database Industri Perkebunan Kelapa Sawit (Hulu - Hilir).

http://dataindustri.blogspot. co.id/2016/05/database-industriperkebunan-kelapa.html

Tesfamariam, D., \& Lindberg, B. (2005). Aggregate Analysis of Manufacturing Systems Using System Dynamics and ANP. Computers \& Industrial Engineering, 49 (1), 98-117.

Toha, M. 2016. Solusi Optimalisasi Industri Tebu Rakyat. http://www. kompasiana.com/mochamadtoha/solusi-optimalisasi-industri-teburakyat_579c68e2f692731a142957e0

Trade Statistics for International Business Development Monthly, quarterly and yearly trade data. Import \& Export values, volumes, growth rates, market shares, etc. 2017. www.trademap.org

Wiradi, G. 1984. Pola Penguasaan Tanah dan Reforma Agraria dalam Tjondronegoro (editor). Dua Abad Penguasaan Tanah. PT Gramedia. Jakarta.

Wolstenholme, E. F. (2003). Towards the Definition and Use of A Core Set of Archetypal Structures in System Dynamics. System Dynamics Review, 19 (1), 7-26. 